\title{
Non covalent immobilization of pyrene-tagged ruthenium complexes onto graphene surfaces for recycling in olefin metathesis reactions
}

Houssein Nasrallah, ${ }^{\mathrm{a}}$ Stéphane Germain, ${ }^{\mathrm{b}}$ Pierre Queval, ${ }^{\mathrm{b}}$ Caroline Bouvier, ${ }^{\mathrm{a}}$ Marc Mauduit, ${ }^{\mathrm{b}}$ Christophe Crévisy ${ }^{\mathrm{b} *}$ and Emmanuelle Schulz ${ }^{\mathrm{a} *}$

\footnotetext{
'Institut de Chimie Moléculaire et des Matériaux d'Orsay, CNRS UMR 8182, Université Paris-Sud, Université Paris-Saclay, bâtiment 420, 91405 Orsay cedex, France 00331691573 56, emmanuelle.schulz@u-psud.fr

${ }^{b}$ Ecole Nationale Supérieure de Chimie de Rennes, CNRS UMR 6226, 11 allée de Beaulieu, CS 50837, 35708 Rennes cedex 7, France 00332232380 74, christophe.crevisy@ensc-rennes.fr
} 


\section{Graphical Abstract}

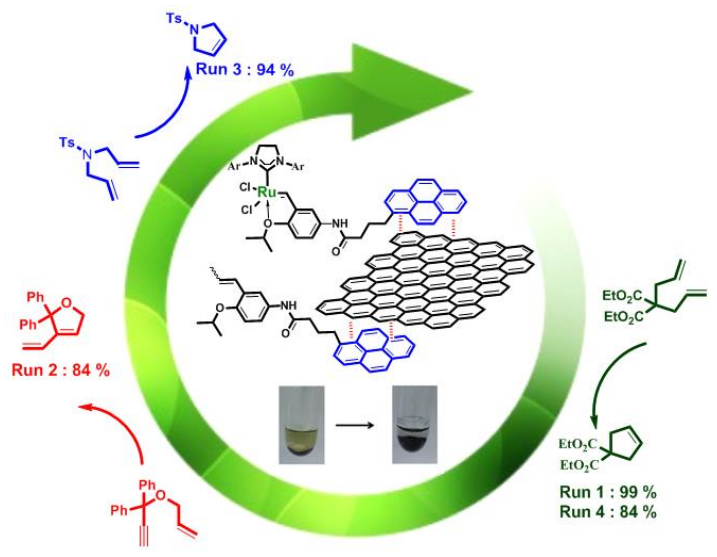

\section{Highlights}

-Synthesis of new pyrene-tagged ruthenium complexes

-Efficient catalysts for olefin metathesis reactions

-Catalyst immobilization on rGO by $\pi$-stacking interactions

- Catalyst/rGO recycling studies in a multisubstrate procedure

-Noticeable positive effect of additional pyrene-tagged styrenylether ligand 


\begin{abstract}
Synthesis of Hoveyda-type ruthenium complexes, modified by pyrene tags on the NHC ligand and/or the benzylidene moiety, is described. Thanks to non-covalent $\pi$ - $\pi$ interactions these new complexes were immobilized on carbon supports [reduced graphene oxide (rGO) or graphene] and their activity and recoverability for metatheses reactions have been studied. A SIPr-based complex possessing the pyrene function on the benzylidene ligand (C2) delivered the best results for the ring closing metathesis of diethyldiallyl malonate as benchmark reaction. The presence of additional pyrene-functionalized styrenyl-ether as ligand to the rGO-supported catalyst (C2/L@rGO) noticeably improved the recycling procedure allowing supplementary efficient catalytic runs. This may be due either to a facilitated boomerang effect or to a gradual release of the active species in solution. Finally, catalyst C2/L@ rGO was proven to be successfully used to promote metathesis reactions in a multisubstrate procedure, the same supported-catalyst batch being successively engaged to transform three different substrates, in diene and ene-yne RCM reactions.
\end{abstract}

\title{
Keywords
}

Metathesis; Ruthenium; Reduced Graphene Oxide; Immobilization; Catalyst Reuse.

\section{Introduction}

Olefin metathesis is undeniably a key reaction for fine organic synthesis[1] and the specific use of ruthenium-based complexes allowed transformations to be selectively run at the very end preparation of complex molecular architectures.[2] Nevertheless, use of such metallic complexes induces high costs and furthermore may lead to some ruthenium leaching in the reaction media, which must be necessarily avoided at least for pharmaceutical applications.[3] In such a context, the search for a compromise is still relevant for the use of highly active catalysts which in turn may reveal low stability. Numerous research teams are thus making significant efforts to develop such species aiming at increasing the turn over number;[4] on the other hand, various studies are ongoing to fine tune recycling methods for efficient homogeneous supported catalysis.[5]

Two different procedures have been studied for grafting the catalytic species on a support, either via a covalent functionalization[6] or thanks to non-covalent interactions.[7] Immobilization of the catalyst through reversible interactions is often more favorable because less demanding in tedious chemical transformations. Furthermore, support recovery may also be envisaged, for instance, after catalyst deactivation. Such strategies have already been described for immobilization of various catalysts through ionic linkage,[8] hydrogen bonding[9] and we also described formation of charge transfer interactions in such a context.[10] Quite recently, use of graphitic surfaces[11] has also been reported for immobilizing homogeneous complexes mainly through strong $\pi, \pi$-interactions between the support and pyrene-tagged ligands. Such carbon materials are rather inert and stable species and they generally possess quite large surface areas. For instance carbon nanotubes (CNT) have already been described as efficient support to immobilize and recover homogeneous 
catalysts via non-covalent interactions. This strategy has already been used to perform asymmetric catalysis; Zhou and his group modified thus enantiomerically pure Pyrphos ligand by a covalent pyrene link and carried out the rhodium-catalysed heterogeneous asymmetric hydrogenation of $\alpha$-dehydroamino esters.[12] Some of us prepared pyrene-tagged bis(oxazoline) copper complexes and proved the efficient reactivity of such complexes immobilized on carbon supports (charcoal, fullerene, single-walled CNT) in promoting Henry and ene reactions under recycling conditions.[13] A similar strategy was developed by Riant and Hermans to immobilize and recycle gold complexes on CNT for enyne cyclisation.[14] Wang and his group also synthesized a pyrene-tagged ruthenium complex and, in the presence of single-walled CNT, they achieved stable and recyclable catalytic species to promote ringclosing metathesis reactions, as the only example of this type of interactions involved for such transformations.[15] Other related supports have been used in this context and particularly carbon-coated magnetic nanoparticles which afford not only catalysts support but also easy handling and recovery by magnetic decantation.[16] Thus pyrene-tagged dendritic palladium catalysts immobilized via $\pi$-stacking on such nanoparticles allowed efficient Suzuki couplings.[17] The group of Mata and Peris[18] interestingly used chemically derived graphenes such as reduced graphene oxide (rGO) for immobilizing pyrene-modified palladium and ruthenium complexes active in various reactions, including a coimmobilization for hydrodefluorination. It is in this context that the present study was set, aiming at immobilizing ruthenium catalysts for recycling experiments in metathesis reactions through ligand modifications by pyrene moieties either at the carbene or benzylidene ligand.

\section{Results and discussion}

\subsection{Catalysts preparation}

A tag dedicated to immobilization can be introduced on a Hoveyda type Ru complex either on the NHC ligand[5,10] or on the benzylidene one.[5,15] As it can be expected that the location of the tag may have a critical influence on the behavior of the resulting pre-catalysts, both options were considered in this study. We decided to synthesize complex C1 (Figure 1) which bears the pyrene group on the NHC ancillary ligand and also a trifluoroacetamido group on the benzylidene ligand. The SIPr-based complex C2 (Figure 1), where the pyrene tag is linked to the benzylidene ligand via an amide bond was also synthesized. As the benzylidene ligand is liberated during the pre-catalyst activation phase, good reusability properties would necessarily arise in this case either from a boomerang mechanism or a reservoir effect.[19] Finally, the influence of the presence of two pyrene tags, hold by both ligands was also tested (complex C3, Figure 1). Moreover, as the presence of a trifluoroacetamido group (found only in C1) or a SiPr (found only in C2) are known to exert some influence on both the activation phase and the stability of the pre-catalysts,[20] differences in the reactivity of these three species were expected.

Complexes $\mathbf{C 1}$ and $\mathbf{C 3}$ were obtained from tagged Ru complex 7 (Scheme 1), which was stemmed from imidazolidinium salt $\mathbf{6}$ and complex $\mathbf{M 1}^{\circledR} \mathrm{RuCl}_{2}\left(\mathrm{PCy}_{3}\right)_{2}$ (Ind) following a standard procedure already employed for the synthesis of similar anthracene-tagged complexes.[10] Imidazolidinium salt 6 was obtained following the convergent strategy 
depicted in Scheme 1. 1-Pyrene methanol was linked to 4-bromo-2,5-dimethylphenol through two successive nucleophilic displacements from 1-bromo-3-chloropropane to afford compound $\mathbf{2}$ in a good overall yield. Besides, crude amide $\mathbf{3}$ was formed by a two steps procedure consisting in a coupling of 2,4,6-trimethylaniline and $N$-Boc-Glycine followed by a removal of the carbamate protecting group. $\mathrm{LiAlH}_{4}$ mediated reduction of the amide group led to the crude diamine 4 in quantitative overall yield over 3 steps. Diamine $\mathbf{4}$ was isolated in a nearly pure form and was engaged in the next step without any further purification. Then, aryl bromide $\mathbf{2}$ and amine $\mathbf{4}$ were coupled using a Buchwald-Hartwig reaction,[21] to give pyrenetagged bis-aniline $\mathbf{5}$ in good isolated yield after purification (81\%). The latter was converted to the tetrafluoroborate imidazolidinium salt $\mathbf{6}$ following a standard procedure. Pure NHC precursor $\mathbf{6}$ was isolated in a good yield (80\%) after precipitation in a $\mathrm{CH}_{2} \mathrm{Cl}_{2} / \mathrm{AcOEt}$ mixture. Imidazolidinium salt 6 was first treated with potassium tert-amylate, thus reacted $1 \mathrm{~h}$ at $80{ }^{\circ} \mathrm{C}$ with Ru complex $\mathbf{M 1}^{\circledR}$ to afford the pyrene-tagged Ru Indenylidene complex $\mathbf{7}$ in high yield $(86 \%)$ after silica gel chromatography.

The synthesis of Hoveyda-type pyrene-tagged complexes C1, C2 and C3 was next undertaken. $\mathrm{N}$-(4-isopropoxy-3-vinylphenyl)-4-(pyren-1-yl)butan-amide 8 (Scheme 2) had to be produced in order to achieve the synthesis of $\mathbf{C 2}$ and $\mathbf{C 3}$, which have a pyrene tag on the benzylidene-ether ligand. Pyrene-tagged compound $\mathbf{8}$ was obtained in good yield (74\%) by a DCC/DMAP mediated coupling between 4-(pyren-1-yl)butanoic acid and known[22] 4isopropoxy-3-vinylaniline hydrochloride.

The Ru complex $\mathbf{7}$ was converted to $\mathbf{M 7}{ }_{1}^{\circledR}{ }^{\circledR}$-type complex $\mathbf{C 1}$ by treatment with 2,2,2-trifluoro$\mathrm{N}$-(4-isopropoxy-3-vinylphenyl)acetamide[23] and $\mathrm{CuCl}$. The latter was isolated in high yield (90\%) after silica gel chromatography followed by a precipitation in a $\mathrm{CH}_{2} \mathrm{Cl}_{2} /$ pentane mixture. The syntheses of complex $\mathbf{C 2}$ and bis-tagged complex $\mathbf{C 3}$ were achieved by reaction of pyrene-tagged styrenyl compound 8 with respectively ( $\mathrm{SIPr}) \mathrm{RuCl}_{2}\left(\mathrm{PPh}_{3}\right)$ (Indenylidene) $\mathbf{M 2 3}^{\circledR}$ and tagged Ru complex 7. The first one was isolated in $60 \%$ yield after being purified by successive washings with $\mathrm{Et}_{2} \mathrm{O}$, whereas the second was obtained in $94 \%$ yield after chromatography then precipitation in a $\mathrm{CH}_{2} \mathrm{Cl}_{2}$ /pentane mixture.

Having the three pre-catalysts in hand, their catalytic activity under homogeneous conditions were first evaluated in ring-closing metathesis (RCM) of substrates S1, S2 and S3 (Scheme 3). The reactions were run in deuterated toluene at $0.2 \mathrm{M}$ and $60{ }^{\circ} \mathrm{C}$ using 100 or $250 \mathrm{ppm}$ of pre-catalyst. The variations of conversions along the time were determined from ${ }^{1} \mathrm{H}$ NMR spectra. The results obtained with diethyl diallylmalonate (DEDAM) S1 are presented in Figure 2.

As expected, C2 exhibits a slower catalyst initiation compared to $\mathbf{C 1}$, as a species immobilized through the benzylidene core. On the other hand, a lower catalyst loading (100 ppm vs. $250 \mathrm{ppm}$ ) was sufficient to reach nearly full conversion with $\mathbf{C 2}$, compared to $\mathbf{C} \mathbf{1}$ and C3. These behavior differences also arise from the different natures of the NHC ancillary ligands (SIPr for C2, SIMes-type for C1 and C3).[24] It must be noted that similar trends 
were observed in the ene-yne RCM of $\mathbf{S 2}$ and the RCM of $N$-tosyldiallylamine $\mathbf{S 3}$ with $\mathbf{C 1}$ and $\mathbf{C 2}$ (see Supporting Information).

\subsection{Immobilization procedure of the catalysts on reduced graphene oxide and ring- closure metathesis of DEDAM}

Aiming at studying their stability on rGO, catalysts $\mathbf{C 1}, \mathbf{C 2}$ and $\mathbf{C 3}$ were immobilized thanks to non-covalent $\pi$-interactions with the graphitic surface. All compounds were therefore dissolved in DCM, and rGO was subsequently added. Immobilization of the Ru-catalysts on the support was identified by UV-visible analyses, following the disappearance of their characteristic signature according to the quantity of added support and the time (see SI for the UV-Visible spectra). Such a procedure led efficiently to the immobilization of $1 \mathrm{mg}$ of $\mathbf{C 1}$ on rGO (20 mg) in 5 hours at room temperature. Accordingly, the same quantity of $\mathbf{C 2}$ could be immobilized on 20 or $40 \mathrm{mg}$ of $\mathrm{rGO}$, and the disappearance of the catalyst in solution occurred almost completely in 7 hours, or 3 hours, respectively. Immobilization of complex C3 (1 mg) on rGO (40 mg) proceeded more slowly, since 24 hours were necessary to get a nearly complete disappearance of complex's signals in the UV spectra. After immobilization, the supported catalysts on $\mathrm{rGO}(\mathbf{C x} @ \mathrm{rGO})$ were recovered by filtration and two successive washings of the black powders with DCM.

These immobilized catalysts were firstly evaluated for their ability to promote the ring-closure metathesis of DEDAM, as benchmark reaction to compare their activity (see eq. 1 in Scheme 3). Different reaction conditions were screened, involving DCM or toluene as solvent mixture and different reaction temperatures. Substrate to catalyst ratio was fixed at 100 , calculated from the initial amount of pre-catalyst deposited on the rGO support. The results are gathered in Table 1.

Catalyst C1@rGO, possessing the pyrene tag fixed on the carbene moiety was tested either in DCM or toluene at $40{ }^{\circ} \mathrm{C}$, delivering in the second case the targeted cyclopentene derivative P1 with a better conversion in 1 hour (entries 1-2). Other catalytic tests were conducted in toluene with various loadings of $\mathbf{C 1} @ \mathrm{rGO}$ and different reaction temperatures, and the best results were obtained in toluene at $50{ }^{\circ} \mathrm{C}$ with a mass ratio $\mathrm{rGO} / \mathrm{C1}$ of 20 (entry 3). Raising the temperature to $60{ }^{\circ} \mathrm{C}$ did indeed not bring improvements probably due to catalyst degradation (entry 4). A similar study was performed working with $\mathbf{C 2} @ \mathrm{rGO}$, for which the importance of the substrate concentration could be demonstrated. Indeed, the reaction in refluxing DCM could allow high conversion of DEDAM with a mass ratio $\mathrm{rGO} / \mathrm{C2}$ of 40 (entries 5-7) with a more concentrated DEDAM solution. In this case again, the use of toluene was beneficial and complete conversion could be observed in only 30 minutes reaction (entry 9). By far much worse results were obtained employing precatalyst $\mathbf{C 3} @$ rGO containing two pyrene tags. In conditions similar to those optimized for the previous catalytic species only low conversions could be observed (entries 10-11).

\subsection{Recycling studies for the RCM of DEDAM}

Accordingly, the ability to recover and reuse the immobilized catalysts was studied in the optimized conditions for each species, i.e. those described in entry 3, Table 1, for $\mathbf{C 1} @ \mathrm{rGO}$ and in entry 9 for C2@rGO; albeit C3@rGO showed only poor efficiency, its behavior for 
recycling was studied in the conditions described in entry 11 . In all cases, the recovery procedure involved direct filtration after the first run and cooling the reaction mixture to room temperature, followed by several washings of the supported catalyst with toluene.

For catalyst $\mathbf{C 1} @ \mathrm{rGO}$, the reaction was performed in toluene at $50{ }^{\circ} \mathrm{C}$, and the reuse of the recovered catalyst in a second run afforded the targeted product $\mathbf{P 1}$ with a significant loss in conversion, which was undeniably confirmed in the third run (see Figure 3). Aiming at reaching a high conversion in a reasonable time, the reaction temperature was raised up to 70 ${ }^{\circ} \mathrm{C}$ for both subsequent runs, delivering $\mathbf{P 1}$ in an increased yield of $62 \%$ in the fourth run, whereas a sharp decrease occurred again in the fifth reuse.

Catalyst C1@rGO, immobilized via non-covalent interactions through the pyrene-tagged carbene ligand, has thus only showed a very low recoverability. We assume that this important loss of activity is related to the generation of an unstable 14 electron active species, immobilized at the rGO surface. Under these conditions, a «boomerang mechanism» postulated for the capture of the ruthenium active species by the styrenyl ether ligand is unlikely to be operative.[19]

Recycling studies were also performed in the presence of catalyst C2@rGO, used in the conditions described in Table 1, entry 9. The immobilization of C2@rGO occurred in this case through $\pi-\pi$ interactions between the support and the pyrene-tagged styrenyl ether, leading thus to the delivery of the 14 electron active species in solution. The results gathered in Table 2, clearly indicate that product 2 was formed in almost complete conversion after 0.5 $\mathrm{h}$ for three successive runs in these conditions (run 1-3). It cannot be concluded, at this stage, if a boomerang effect is occurring in some extent to recover the catalyst on the support or if the support operates as a reservoir, allowing the sequential release of sufficient catalytic species to afford high yield.

Two supplementary runs were conducted at higher temperature for comparison with the study performed with C1.[25] A marked decrease in the conversion values occurred (runs 4-5) even if product $\mathbf{P 1}$ was still obtained in up to $62 \%$ conversion, in a slightly prolonged reaction time. Under these conditions, catalyst C2@rGO performed better than C1@rGO in terms of TON (440 compared to 318 ), but rapid deactivation cannot be ruled out in this case either.

Attempts to reuse $\mathbf{C 3 @ r G O ~ a n a l o g o u s l y ~ i n ~ s e v e r a l ~ c a t a l y t i c ~ r u n s ~ f a i l e d , ~ w h e n ~ t h e ~ r e a c t i o n s ~}$ were performed in toluene at $60{ }^{\circ} \mathrm{C}$ (see Table 1, entry 11). After a first $28 \%$ conversion reached after one hour reaction, the first reuse of this supported catalyst only delivered indeed $9 \%$ conversion and the subsequent $3^{\text {rd }}$ run led to $3 \%$ conversion. The potential degradation of C3 in solution at $60{ }^{\circ} \mathrm{C}$ was therefore studied and NMR studies were conducted in deuterated chloroform for solubility reasons (see SI for details). During the first two hours, about 20 to $25 \%$ of the initial concentration of complex was lost and then the rate of degradation significantly decreased but still resulted in a loss of $50 \%$ of the complex after six days. It can be concluded that the poor behavior of $\mathbf{C 3 @ r G O ~ t o w a r d s ~ c a t a l y t i c ~ e f f i c i e n c y ~ a n d ~}$ recyclability cannot mainly result from an insufficient intrinsic stability of $\mathbf{C 3}$. On the other hand it could be linked to the slower immobilization of $\mathbf{C 3}$ on rGO (vide supra). 
C2@rGO led to the best results for this recycling study among the three supported catalysts, and this complex, immobilized through the styrenyl part of its structure, was thus chosen for the following study.

\subsection{Recycling studies in the presence of additional styrenylether as ligand}

The recycling ability of $\mathbf{C 2} @ \mathrm{rGO}$ incontestably has to be improved to be a valuable procedure for running metathesis transformations, at least to be competitive from a practical point of view.[26,27] Although there is an ongoing discussion, recyclability of some ruthenium complexes has been associated with the ability of the styrenylether ligand to recoordinate the $14 \mathrm{e}^{-}$metal centre, the so-called boomerang effect, in the termination step, leading to the formation of a stable species.[19] In this context, ligand $\mathbf{L}$ (see scheme 4) was synthesized starting from known 4-isopropoxy-3-(prop-1-en-1-yl)aniline hydrochloride[8b] by an analogous procedure to the one reported in scheme 2 for obtaining 8 (details for this transformation are given in experimental section).

Catalysis of DEDAM metathesis was thus evaluated with C2@rGO in the presence of additional styrenyl ether $\mathbf{L}$ aiming at favoring final complexation of the ligand towards better stabilization. Very efficient immobilization of $\mathbf{L}$ on rGO was confirmed by UV-visible analysis with a complete disappearance of the species in solution (see supporting information). The immobilization procedure was therefore performed again in DCM with the first impregnation of $\mathbf{C 2}(\mathbf{C} 2 / \mathrm{rGO}=1 / 40)$ during $3 \mathrm{~h}$ and 4 equiv. of $\mathbf{L}$ were then added for an additional hour of stirring at room temperature. The modified support was in this case again recovered by filtration, washed twice with DCM and dried under vacuum. A kinetic monitoring of DEDAM metathesis promoted by C2@rGO in the presence or without additional ligand was thus performed and results are gathered in Figure 4. Reactions were performed in toluene at $40{ }^{\circ} \mathrm{C}$ with a somewhat lower concentration of DEDAM $(0.1 \mathrm{M})$, reducing the catalysts activity to better assess their difference.

Satisfyingly, the effect of the presence of the additional ligand is significant in this reaction, accompanied by a sharp reduction in the initial activity of the catalyst. This decrease is not surprising considering the presence of the ligand in excess, which stabilizes the pre-catalytic species during the initiation step.[6e,28] Recycling studies were then performed in these conditions and compared to the results obtained with the simple catalytic system $\mathbf{C 2} @ \mathrm{rGO}$ (see Table 3).

A strong positive effect of the additional $\mathbf{L}$ ligand is clear for this transformation since 7 runs could be performed with the system C2/L@rGO. Considering for instance runs 4 and 5 in both cases (entries 4 and 6), an improvement in initial activity is obvious for the first thirty minutes of reaction. It may thus be concluded that the presence of additional ligand resulted in the stabilization of the Ru-complex leading to a greater amount of active catalytic species in these late runs, either by boomerang or reservoir effect. 


\subsection{Recycling on graphene}

The joint use of complex $\mathbf{C 2}$ and extra ligand $\mathbf{L}$ allowed reaching a more recyclable rGObased catalytic material. Another possible explanation of the fruitful role of the extra ligand would be an undeniable more extensive coverage of the rGO surface and a subsequent protection of the sensitive active $\mathrm{Ru}$ species against potential support damaging effects. Indeed, rGO contains various oxygenated functional groups such as hydroxyl, carboxylic, carbonyl, epoxide[29] which may be involved in the catalyst degradation process. Consequently, it could be anticipated that the use of graphene which is a similar material but lacking these oxygen functionalities could lead to a higher reusability. Complex $\mathbf{C 2}$ was thus immobilized on graphene, during $5 \mathrm{~h}$ in $\mathrm{CH}_{2} \mathrm{Cl}_{2}$ at room temperature.[30] The immobilized complex was recovered by centrifugation and removal of the supernatant. This was followed by two washing steps of the powder, consisting of the addition of fresh solvent and a centrifugation. Finally, the resulting material was tested in the RCM of DEDAM S1, and the results are given in Table 4. Although complete conversion was obtained for the first run in toluene at $60{ }^{\circ} \mathrm{C}$, the recyclability was not improved compared to the one reached with the rGO-based material since a very low conversion (12\%) was attained at the third run (entries 1 3, Table 4 vs. Table 2). Nevertheless, when the reactions were run in $\mathrm{CH}_{2} \mathrm{Cl}_{2}$, slightly better results were obtained as conversion decreased only slightly for the third run (87\%) but was then more significantly reduced at the $4^{\text {th }}$ run $(47 \%)$. Consequently, the next studies were undertaken using the catalytic material based on rGO and complex $\mathbf{C 2}$, in toluene as the best results in terms of catalyst reuse were reached under these conditions.

\subsection{C2/L@ @GO as reusable catalyst in a multisubstrate procedure}

Demonstration of the scope of such a recovery process was performed through a multisubstrate procedure, for which different substrates were engaged in various metathesis reactions, at each recycling of the immobilized catalyst, C2/L@ rGO. The initial catalyst loading introduced is $1 \mathrm{~mol} \%$ and reactions are performed at $60{ }^{\circ} \mathrm{C}$ in toluene, with a concentration of each substrate of $0.2 \mathrm{M}$. Two ring closing metatheses were considered as benchmark reaction (see scheme 3), with the already discussed cyclization of DEDAM to produce $\mathbf{P 1}$ and the transformation of $N, N$-diallyl-4-methyl-benzenesulfonamide $\mathbf{S 3}$ to yield the targeted dihydropyrrole P3. Furthermore, the activity of C2/L@rGO in an ene-yne reaction was evaluated for the formation of the dihydrofurane derivative P2. Results are gathered in Table 5.

The first reaction concerned the optimized conversion of DEDAM and product P1 was isolated in quantitative yield after $1 \mathrm{~h}$ reaction in toluene at $60{ }^{\circ} \mathrm{C}$. The catalyst recovered by filtration was directly engaged in the ene-yne transformation of $\mathbf{S 2}$ delivering $\mathbf{P 2}$ with a complete conversion in a short reaction time. Here again, the pure product was nicely isolated in very high yield. Similar behavior was noticed for the $3^{\text {rd }}$ use of the same catalytic batch for the easy synthesis of $\mathbf{P 3}$ in $94 \%$ yield. The $4^{\text {th }}$ use of $\mathbf{C 2} / \mathbf{L} @ \mathrm{rGO}$ was dedicated again to the RCM of DEDAM S1, which occurred under harsher conditions, but allowed the synthesis of $\mathbf{P 1}$ in $84 \%$ yield. Subsequent formation of $\mathbf{P 2}$ in a fifth run remained however limited.

Beyond, we wish to stress here that this procedure, which involves the use of a substrate with a different structure for each use of the catalytic system, allows yet the isolation of each 
targeted product in its pure form, without contamination of the preceding run and in high yield.

\section{Conclusion}

Three novel Hoveyda-type ruthenium complexes have thus been synthesized, possessing pyrene moieties for their non-covalent grafting on carbon surfaces, either at the NHC or at the benzylidene ether ligand. Aiming at studying their recycling for olefin metathesis reactions, C2@rGO delivered the best results of the study, as a pre-catalyst bearing the pyrene tag on the benzylidene moiety. Recovery occurred after simple filtration of the solid catalytic species at room temperature and addition of a renewed batch of substrate. Five reuses of C2@rGO could be performed in these conditions for the RCM of DEDAM albeit accompanied with a loss in efficiency, essentially in the $4^{\text {th }}$ and $5^{\text {th }}$ runs. Interestingly, addition of pyrene-tagged styrenylether as supplementary ligand immobilized on rGO allowed tangible improvement of the catalytic results. This may be due to a facilitated boomerang effect to stabilize the active ruthenium species from the solution, made possible by an increased concentration of benzylidene ligands on the support. However, at that point it cannot be excluded that this additional ligand, which has been showed to slow down the initiation phase, also increases the reservoir effect, and thus the gradual release of the active species. $\mathbf{C 3}$ pre-catalyst possessing two pyrene tags on the NHC and on the benzylidene ether moieties has been synthesized to attempt improving further the recycling but this has not led to success. Although this is not supported by any experimental evidence, we propose that sterical hindrance generated by the support for this doubly anchored catalyst may be harmful for precatalyst activation and/or efficient boomerang effect. Nevertheless, catalyst C2/L@rGO was successfully used to promote metatheses reactions in a multisubstrate procedure, the same catalyst batch being successively used to transform three different substrates, in diene and ene-yne RCM reactions. Four efficient runs were performed with high yields, the last fifth run delivering the targeted product in an only low conversion. Clearly, this preliminary study cannot be a conclusive answer to the challenge of conducting metatheses reactions in the presence of supported stabilized ruthenium catalysts. It nevertheless describes the first use of rGO as support for such sensitive catalysts, as far as we know, and its successful use in recycling methodologies for metathesis reactions.

\section{Experimental section}

\subsection{General Information}

All manipulations were carried out under an argon atmosphere by using standard Schlenk techniques. Commercially available products were used as received unless otherwise stated. Diethyldiallylmalonate $\mathbf{S 1}$ was purified by passing through neutral alumina and stored under argon. Enyne S2 was prepared from 1,1-diphenylpropyn-1-ol,[31] and N,N-diallyl-4-methylbenzenesulfonamide $\mathbf{S 3}$ from diallylamine,[32] according to reported procedures. rGO was purchased from Graphenea (1 g, BET surface area: $422.69-499.85 \mathrm{~m}^{2} / \mathrm{g}$, elemental analysis : $\mathrm{C}(\%): 77-87 \%, \mathrm{H}(\%): 0-1 \%, \mathrm{~N}(\%): 0-1 \%, \mathrm{O}(\%): 13-22)$ and used as received. Graphene was purchased from Alfa Aesar $(25 \mathrm{~g}$, Graphene nanoplatelets aggregates, submicronparticles, S.A. $500 \mathrm{~m}^{2} / \mathrm{g}$ ) and used as received. THF, $\mathrm{Et}_{2} \mathrm{O}$ and toluene were dried and 
distilled from sodium/benzophenone ketyl, $\mathrm{CH}_{2} \mathrm{Cl}_{2}$ was dried and distilled from $\mathrm{CaH}_{2} .{ }^{1} \mathrm{H}$ $(400 \mathrm{MHz}),{ }^{13} \mathrm{C}(101 \mathrm{MHz}),{ }^{19} \mathrm{~F}(376 \mathrm{MHz}),{ }^{31} \mathrm{P}(162 \mathrm{MHz})$ and ${ }^{11} \mathrm{~B}(128 \mathrm{MHz}) \mathrm{NMR}$ spectra were recorded on a Bruker ARX400 spectrometer with complete proton decoupling for nucleus other than ${ }^{1} \mathrm{H} .{ }^{1} \mathrm{H}$ and ${ }^{13} \mathrm{C}$ chemical shifts are reported in parts per million with the solvent resonance as internal standard $\left(\mathrm{CDCl}_{3},{ }^{1} \mathrm{H}: \delta=7.26 \mathrm{ppm},{ }^{13} \mathrm{C}: \delta=77.16 \mathrm{ppm} ; \mathrm{CD}_{2} \mathrm{Cl}_{2}\right.$, $\left.{ }^{1} \mathrm{H}: \delta=5.32,{ }^{13} \mathrm{C}: \delta=53.8 \mathrm{ppm}\right) ;{ }^{11} \mathrm{~B}$ chemical shifts are reported in parts per million with $\mathrm{BF}_{3}-\mathrm{OEt}_{2}(\delta=0.0 \mathrm{ppm})$ as internal standard; ${ }^{19} \mathrm{~F}$ chemical shifts are reported in parts per million with $\mathrm{CFCl}_{3}(\delta=0.0 \mathrm{ppm})$ as internal standard; ${ }^{31} \mathrm{P}$ chemical shifts are reported in parts per million with $\mathrm{H}_{3} \mathrm{PO}_{4}(\delta=0.0 \mathrm{ppm})$ as internal standard. Coupling constants are reported in Hertz $(\mathrm{Hz})$. Abbreviations are used as follows: $\mathrm{s}=$ singlet, $\mathrm{d}=$ doublet, $\mathrm{t}=$ triplet, $\mathrm{q}=$ quartet, quin $=$ quintuplet, sept $=$ septuplet, $\mathrm{m}=$ multiplet, br. $=$ broad. Melting points were measured on a Stuart SMP10 apparatus. High-resolution mass spectroscopy (HR-MS, ESI) analyses and elemental analysis were performed at the Centre Régional de Mesures Physiques de 1'Ouest (CRMPO), Université de Rennes 1. HR-MS (ESI) analyses were recorded on a Bruker Maxis 4G, Waters Q-Tof 2 or Thermo-fisher Q-Exactive spectrometer. Elemental analyses were recorded on Microanalyseur Flash EA1112. HR-MS (MALDI-Tof) analyses were performed on Bruker Daltonics Ultraflex III at Institut des Sciences Analytiques, Dept. Service Central d'Analyse, CNRS, Villeurbanne. GC analyses were performed on a GC Shimadzu 2010-Plus, FID, SSL. UV-Visible experiments were realized on a Varian, Cary 300 Bio or Shimadzu, UV-1605 spectrophotometers.

\subsection{Synthesis of $\mathrm{C} 1, \mathrm{C} 2$ and $\mathrm{C} 3$}

2-bromo-5-(3-chloropropoxy)-1,3-dimethylbenzene (1): In a round bottomed flask, 4bromo-3,5-dimethylphenol (4.02 g, $20 \mathrm{mmol})$, 1-bromo-3-chloropropane (2.1 mL, $21 \mathrm{mmol})$ and $\mathrm{K}_{2} \mathrm{CO}_{3}(3.04 \mathrm{~g}, 22 \mathrm{mmol})$ were refluxed in acetone $(40 \mathrm{~mL})$ for $3 \mathrm{~d}$. After cooling down to $\mathrm{rt}$ the mixture was filtered and the filtrate evaporated under reduced pressure. Intermediate 1 was isolated nearly pure as a colorless oil and was used without further purification $(5.55 \mathrm{~g}$, quantitative). ${ }^{1} \mathrm{H} \mathrm{NMR}\left(400 \mathrm{MHz}, \mathrm{CDCl}_{3}\right) \delta=6.66$ (br.s, $2 \mathrm{H}$ ), 4.07 (t, $J=5.9 \mathrm{~Hz}, 2 \mathrm{H}$ ), 3.73 $(\mathrm{t}, J=6.3 \mathrm{~Hz}, 2 \mathrm{H}), 2.38(\mathrm{~s}, 6 \mathrm{H}), 2.22(\mathrm{tt}, J=6.3,6.1 \mathrm{~Hz}, 2 \mathrm{H}) .{ }^{13} \mathrm{C} \mathrm{NMR}\left(101 \mathrm{MHz}, \mathrm{CDCl}_{3}\right) \delta$ $=157.3,139.3,118.6,114.6,64.5,41.6,32.4,24.2$. HR-MS (ASAP) $: \mathrm{m} / \mathrm{z}=276.9992$, calcd. for $\mathrm{C}_{11} \mathrm{H}_{15} \mathrm{O}^{35} \mathrm{Cl}^{79} \mathrm{Br}[\mathrm{M}+\mathrm{H}]^{+}: 276.99893$ (1 ppm).

1-((3-(4-bromo-3,5-dimethylphenoxy)propoxy)methyl)-pyrene (2): In a round bottomed flask, 1 (5.55 g, $20 \mathrm{mmol})$, 1-pyrenemethanol (4.65 g, $20 \mathrm{mmol})$ and $n$-Bu4NBr (645 mg, 2 mmol) were placed in a $\mathrm{NaOH}(\mathrm{aq})$ solution $(0.72 \mathrm{M}, 70 \mathrm{~mL}, 50 \mathrm{mmol})$ and the mixture was refluxed for $6 \mathrm{~d}$. After cooling down to $\mathrm{rt}$ the resulting biphasic mixture was extracted with $\mathrm{CH}_{2} \mathrm{Cl}_{2}$ (3x100mL), the combined organic phases were washed with brine, dried over $\mathrm{MgSO}_{4}$, filtered and evaporated under reduced pressure. The crude product was purified by flash chromatography on silica gel (pentane/ $\mathrm{CH}_{2} \mathrm{Cl}_{2}, 1: 1$ ) followed by recrystallisation from $\mathrm{EtOH} / \mathrm{CHCl}_{3}(8: 2)$ leading to light yellow crystals of pure $2(5.94 \mathrm{~g}, 63 \%) . \mathrm{Mp}=101{ }^{\circ} \mathrm{C} .{ }^{1} \mathrm{H}$ NMR $\left(400 \mathrm{MHz}, \mathrm{CDCl}_{3}\right) \delta=8.31(\mathrm{~d}, J=9.2 \mathrm{~Hz}, 1 \mathrm{H}), 8.18(\mathrm{dd}, J=7.6,1.2 \mathrm{~Hz}, 1 \mathrm{H}), 8.15$ $(\mathrm{dd}, J=7.7,1.1 \mathrm{~Hz}, 1 \mathrm{H}), 8.11(\mathrm{~d}, J=7.7 \mathrm{~Hz}, 1 \mathrm{H}), 8.07-7.97(\mathrm{~m}, 4 \mathrm{H}), 7.95(\mathrm{~d}, J=9.2 \mathrm{~Hz}$, 1H), 6.45 (br.s, 2H), 5.22 (s, 2H), 3.95 (t, $J=6.0 \mathrm{~Hz}, 2 \mathrm{H}), 3.79$ (t, $J=5.9 \mathrm{~Hz}, 2 \mathrm{H}$ ), 2.26 (br.s, $6 \mathrm{H}), 2.06(\mathrm{tt}, J=6.0,6.0 \mathrm{~Hz}, 2 \mathrm{H}) .{ }^{13} \mathrm{C} \mathrm{NMR}\left(101 \mathrm{MHz}, \mathrm{CDCl}_{3}\right) \delta=157.4,138.9,131.5$, $131.5,131.3,130.9,129.6,127.8,127.6,127.5,127.3,126.1,125.4,125.3,125.1,124.8$, 
124.5, 123.6, 118.1, 114.3, 72.0, 66.3, 64.6, 29.9, 24.1. HR-MS (ESI): m/z = 495.0931, calcd. for $\mathrm{C}_{28} \mathrm{H}_{25} \mathrm{O}_{2} \mathrm{BrNa}[\mathrm{M}+\mathrm{Na}]^{+}$: 495.0930 (0 ppm).

2-amino- $N$-mesitylacetamide (3): In a dry round bottomed flask were placed $N$-Boc-glycine (1.5 g, $8.56 \mathrm{mmol}), N$-methylmorpholine $(940 \mu \mathrm{L}, 8.56 \mathrm{mmol})$ and THF (30 mL). Isobutylchloroformate $(1.1 \mathrm{~mL}, 8.56 \mathrm{mmol})$ was added dropwise at $0{ }^{\circ} \mathrm{C}$ and the mixture was stirred for 30 minutes at this temperature. Then 2,4,6-trimethylaniline $(1.2 \mathrm{~mL}, 8.56 \mathrm{mmol})$ was added at $0{ }^{\circ} \mathrm{C}$ and the stirring kept for $5 \mathrm{~h}$ at $\mathrm{rt}$. The solvent was removed under reduced pressure and the resulting solid was dissolved in ethyl acetate $(30 \mathrm{~mL})$. The organic phase was successively washed with saturated aqueous solution of $\mathrm{NaHCO}_{3}(20 \mathrm{~mL}), 1 \mathrm{M} \mathrm{HCl}(20 \mathrm{~mL})$ and brine $(20 \mathrm{~mL})$, dried over $\mathrm{MgSO}_{4}$, filtered and the solvent was removed under reduced pressure. The resulting solid was dissolved in $\mathrm{MeOH}(15 \mathrm{~mL})$ under argon and a $2 \mathrm{M}$ solution of $\mathrm{HCl}$ in $\mathrm{MeOH}\left(43 \mathrm{~mL}, 85.6 \mathrm{mmol}\right.$ ) was slowly added at $0{ }^{\circ} \mathrm{C}$ then the mixture was stirred at $\mathrm{rt}$ for $14 \mathrm{~h}$ whereupon a white precipitate was formed. The mixture was concentrated under reduced pressure and dissolved in $\mathrm{CH}_{2} \mathrm{Cl}_{2}(30 \mathrm{~mL})$. The organic layer was successively washed with an aqueous solution of $1 \mathrm{M} \mathrm{NaOH}(60 \mathrm{~mL})$ and brine $(30 \mathrm{~mL})$, dried over $\mathrm{MgSO}_{4}$, filtered and the solvent was removed under reduced pressure to afford crude glycylmesidide 3 as a white solid (1.65 g). Crude $\mathbf{3}$ was sufficiently pure to be used without further purification. $\mathrm{Mp}=119{ }^{\circ} \mathrm{C} .{ }^{1} \mathrm{H} \mathrm{NMR}\left(400 \mathrm{MHz}, \mathrm{CDCl}_{3}\right) \delta=8.69$ (br.s, 1H), 6.90 (br.s, $2 \mathrm{H}), 3.54$ (s, 2H), 2.26 (s, 3H), 2.19 (s, 6H), 1.61 (br.s, 2H). ${ }^{13} \mathrm{C} \mathrm{NMR}\left(101 \mathrm{MHz}, \mathrm{CDCl}_{3}\right) \delta=$ 171.2, 136.8, 134.9, 131.2, 129.0, 45.1, 21.0, 18.5. HR-MS (ESI): $\mathrm{m} / \mathrm{z}=215.1170$, calcd. for $\mathrm{C}_{11} \mathrm{H}_{16} \mathrm{~N}_{2} \mathrm{ONa}[\mathrm{M}+\mathrm{Na}]^{+}: 215.1160$ (5 ppm).

$\mathrm{N}$-mesitylethane-1,2-diamine (4): In a dry round bottomed flask equipped with a condenser was suspended under argon $\mathrm{LiAlH}_{4}(1.95 \mathrm{~g}, 51.4 \mathrm{mmol})$ in dry THF $(20 \mathrm{~mL})$. A solution of crude 3 (1.65 g, $8.56 \mathrm{mmol})$ in $20 \mathrm{~mL}$ of dry THF was then slowly added at $0{ }^{\circ} \mathrm{C}$ after what the mixture was stirred at reflux for $3 \mathrm{~d}$. After cooling down to $0{ }^{\circ} \mathrm{C}, \mathrm{H}_{2} \mathrm{O}(3.08 \mathrm{~mL})$ then 15 $\%$ aqueous $\mathrm{NaOH}(3.08 \mathrm{~mL})$ were slowly added under air, the mixture was then filtered on a celite bed and washed with AcOEt. Solvents were removed under reduced pressure to afford 4 as a colorless oil (1.52 g, quantitative over 3 steps from 2,4,6-trimethylaniline to compound 4). Crude 4 was isolated nearly pure and used without further purification. Data were consistent with previously reported values.[33] ${ }^{1} \mathrm{H} \mathrm{NMR}\left(400 \mathrm{MHz}, \mathrm{CDCl}_{3}\right) \delta=6.83-6.81$ (m, 2H), $3.00-2.95(\mathrm{~m}, 2 \mathrm{H}), 2.92-2.88(\mathrm{~m}, 2 \mathrm{H}), 2.28(\mathrm{~s}, 6 \mathrm{H}), 2.23$ (s, 3H), 1.85 (br.s, 3H). ${ }^{13} \mathrm{C}$ NMR $\left(101 \mathrm{MHz}, \mathrm{CDCl}_{3}\right) \delta=143.7,131.4,129.9,129.6,51.5,42.7,20.7,18.5$.

\section{N1-(2,6-dimethyl-4-(3-(pyren-1-ylmethoxy)propoxy)-phenyl)-N2-mesitylethane-1,2-}

diamine (5): In a dry round bottomed flask under argon ( $\mathrm{rac}$.)-BINAP (99.6 mg, $0.16 \mathrm{mmol}$ ) was solubilized in toluene $(4.6 \mathrm{~mL})$ at $80{ }^{\circ} \mathrm{C}$. After cooling down to $\mathrm{rt} \mathrm{Pd}(\mathrm{OAc})_{2}(35.9 \mathrm{mg}$, $0.16 \mathrm{mmol}$ ) was introduced as a solid in one portion and the solution was stirred for $1 \mathrm{~min}$. until complete dissolution of the solid. This solution was then introduced at $\mathrm{rt}$ into a schlenk tube containing bromoarene $2(946.8 \mathrm{mg}, 2 \mathrm{mmol})$, amine $4(356.5 \mathrm{mg}, 2 \mathrm{mmol})$ and $t$ $\mathrm{BuONa}(250 \mathrm{mg}, 2.6 \mathrm{mmol})$ in toluene $(3.1 \mathrm{~mL})$ under argon. The mixture was heated at 110 ${ }^{\circ} \mathrm{C}$ overnight and after cooling down to rt AcOEt $(60 \mathrm{~mL})$ was added. The organic phase was filtered over celite and then successively washed with saturated $\mathrm{NH}_{4} \mathrm{Cl}(60 \mathrm{~mL})$ and brine, dried over $\mathrm{MgSO}_{4}$, filtered and evaporated under reduced pressure to afford a brown oil. The latter was purified by chromatography over silica gel (cycohexane/AcOEt, $85: 15$ ) giving 5 as a light brown oil $(924 \mathrm{mg}, 81 \%){ }^{1} \mathrm{H} \mathrm{NMR}\left(400 \mathrm{MHz}, \mathrm{CDCl}_{3}\right) \delta=8.35(\mathrm{~d}, J=9.2 \mathrm{~Hz}, 1 \mathrm{H})$, 
8.18 (ddd, $J=7.8,5.0,1.2 \mathrm{~Hz}, 2 \mathrm{H}), 8.14(\mathrm{~d}, J=7.7 \mathrm{~Hz}, 1 \mathrm{H}), 8.06(\mathrm{~s}, 2 \mathrm{H}), 8.05-7.98(\mathrm{~m}$, $3 \mathrm{H}), 6.85-6.83(\mathrm{~m}, 2 \mathrm{H}), 6.55-6.53(\mathrm{~m}, 2 \mathrm{H}), 5.24(\mathrm{~s}, 2 \mathrm{H}), 4.02(\mathrm{t}, J=6.2 \mathrm{~Hz}, 2 \mathrm{H}), 3.82(\mathrm{t}, J$ $=6.1 \mathrm{~Hz}, 2 \mathrm{H}), 3.20$ (br.s, 2H), $3.19-3.14(\mathrm{~m}, 2 \mathrm{H}), 3.11-3.07(\mathrm{~m}, 2 \mathrm{H}), 2.31(\mathrm{~s}, 6 \mathrm{H}), 2.26(\mathrm{~s}$, $6 \mathrm{H}), 2.25(\mathrm{~s}, 3 \mathrm{H}), 2.11(\mathrm{tt}, J=6.1,6.1 \mathrm{~Hz}, 2 \mathrm{H}) .{ }^{13} \mathrm{C}$ NMR $\left(101 \mathrm{MHz}, \mathrm{CDCl}_{3}\right) \delta=154.4$, $143.5,139.0,131.9,131.4,131.3,131.2,130.8,129.7,129.6,129.4,127.6,127.4,127.3$, $126.9,125.9,125.2,125.1,124.9,124.7,124.4,123.5,114.7,71.7,66.9,64.8,49.5,49.2$, 30.0, 20.6, 18.6, 18.5. HR-MS (ESI): $\mathrm{m} / \mathrm{z}=571.3319$, calcd. for $\mathrm{C}_{39} \mathrm{H}_{43} \mathrm{~N}_{2} \mathrm{O}_{2}[\mathrm{M}+\mathrm{H}]^{+}$: $571.3314(1 \mathrm{ppm})$.

\section{1-(2,6-dimethyl-4-(3-(pyren-1-ylmethoxy)propoxy)-phenyl)-3-mesityl-4,5-dihydro-1H-}

imidazol-3-ium tetrafluoroborate (6): In a dry round-bottomed flask, 5 (924 mg, 1.62 mmol) was solubilised in $\mathrm{Et}_{2} \mathrm{O}(8 \mathrm{~mL})$ under argon. A $2 \mathrm{M}$ solution of $\mathrm{HCl}$ in $\mathrm{MeOH}(1.1 \mathrm{~mL}$, $1.62 \mathrm{mmol}$ ) was slowly added at $0{ }^{\circ} \mathrm{C}$ whereupon a white precipitate was formed, the mixture was stirred for 10 more minutes at $\mathrm{rt}$ The solvents were removed under reduced pressure and the resulting solid was partially dissolved in toluene $(5 \mathrm{~mL})$ under argon. Trimethylorthoformate $(1.6 \mathrm{~mL})$ was added at $\mathrm{rt}$, the flask was equipped with a condenser and the mixture stirred at $100{ }^{\circ} \mathrm{C}$ overnight. After cooling down to $\mathrm{rt}$ the volatiles were evaporated under reduced pressure and the resulting solid was dissolved in $\mathrm{CH}_{2} \mathrm{Cl}_{2}(5 \mathrm{~mL}) . \mathrm{KBF}_{4}(407.6$ $\mathrm{mg}, 3.24 \mathrm{mmol}$ ) and few drops of $\mathrm{H}_{2} \mathrm{O}$ were added and the mixture was stirred for $4 \mathrm{~h}$. To the mixture, $\mathrm{CH}_{2} \mathrm{Cl}_{2}(30 \mathrm{~mL})$ was added and the organic layer was washed with $\mathrm{H}_{2} \mathrm{O}(2 \times 20 \mathrm{~mL})$, dried over $\mathrm{MgSO}_{4}$, filtered and the solvent was removed under reduced pressure. The resulting brown solid was dissolved in a minimum amount of $\mathrm{CH}_{2} \mathrm{Cl}_{2}$ and precipitate by addition of AcOEt giving 6 as a white solid $(868 \mathrm{mg}, 80 \%) . \mathrm{Mp}=168{ }^{\circ} \mathrm{C} .{ }^{1} \mathrm{H}$ NMR (400 $\left.\mathrm{MHz} \mathrm{CDCl}_{3}\right) \delta=8.28(\mathrm{~d}, J=9.2 \mathrm{~Hz}, 1 \mathrm{H}), 8.08(\mathrm{dd}, J=7.7,1.1 \mathrm{~Hz}, 1 \mathrm{H}), 8.05(\mathrm{~d}, J=7.8 \mathrm{~Hz}$, $1 \mathrm{H}), 8.02(\mathrm{dd}, J=7.7,1.1 \mathrm{~Hz}, 1 \mathrm{H}), 7.99-7.92(\mathrm{~m}, 4 \mathrm{H}), 7.87(\mathrm{t}, J=7.6 \mathrm{~Hz}, 1 \mathrm{H}), 7.24(\mathrm{~s}, 1 \mathrm{H})$, $6.91(\mathrm{~s}, 2 \mathrm{H}), 6.27(\mathrm{~s}, 2 \mathrm{H}), 5.15(\mathrm{~s}, 2 \mathrm{H}), 4.41-4.26(\mathrm{~m}, 4 \mathrm{H}), 3.90(\mathrm{t}, J=6.0 \mathrm{~Hz}, 2 \mathrm{H}), 3.76(\mathrm{t}, J$ $=5.8 \mathrm{~Hz}, 2 \mathrm{H}), 2.28(\mathrm{~s}, 3 \mathrm{H}), 2.23(\mathrm{~s}, 6 \mathrm{H}), 2.07-1.98(\mathrm{~m}, 8 \mathrm{H}) .{ }^{13} \mathrm{C} \mathrm{NMR}\left(101 \mathrm{MHz}, \mathrm{CDCl}_{3}\right) \delta$ $=159.5,158.7,140.6,136.5,135.1,131.6,131.2,131.1,130.8,130.1,130.0,129.4,127.6$, $127.5,127.3,127.3,126.0,125.2,125.1,124.8,124.8,124.5,124.5,123.7,114.5,71.7,66.0$, 64.6, 51.7, 51.6, 29.6, 21.2, 17.6, 17.5. ${ }^{11} \mathrm{~B}$ NMR $\left(128 \mathrm{MHz}, \mathrm{CDCl}_{3}\right) \delta=-1.1 .{ }^{19} \mathrm{~F}$ NMR $(376$ $\left.\mathrm{MHz}, \mathrm{CDCl}_{3}\right) \delta=-152.9,-153.0$. HR-MS (ESI): $\mathrm{m} / \mathrm{z}=581.3163$, calcd. for $\mathrm{C}_{40} \mathrm{H}_{41} \mathrm{~N}_{2} \mathrm{O}_{2}$ [M$\left.\mathrm{BF}_{4}\right]^{+}: 581.3168$ (1 ppm).

Ruthenium complex (7): In the glovebox, a Schlenk tube was charged with imidazolidinium salt $6(300 \mathrm{mg}, 0.45 \mathrm{mmol})$ suspended in toluene $(4.3 \mathrm{~mL})$ and potassium tert-amylate $(254$ $\mu \mathrm{L}, 1.7 \mathrm{M}$ in toluene, $0.43 \mathrm{mmol}$ ) was added. The mixture was stirred for 30 minutes then to the clear solution $\mathrm{RuCl}_{2}\left(\mathrm{PCy}_{3}\right)_{2}$ (Indenylidene) (318.6 mg, $0.35 \mathrm{mmol}$ ) was added as a solid in one portion. The Schlenk tube was sealed, then taken out of the glovebox and placed in an oil bath at $80{ }^{\circ} \mathrm{C}$ for $1 \mathrm{~h}$. The mixture was concentrated under reduced pressure and purified as such by flash chromatography on silica gel with cyclohexane/AcOEt (95:5), then cyclohexane/Et $2 \mathrm{O}(7: 3)$ giving 7 as a red solid (364 mg, $\left.86 \%){ }^{1} \mathrm{H} \mathrm{NMR} \mathrm{(400} \mathrm{MHz}, \mathrm{CDCl}_{3}\right)(2$ conformers $) \delta=8.67-8.61(\mathrm{~m}, 1 \mathrm{H}), 8.39(\mathrm{~d}, J=9.2 \mathrm{~Hz}, 0.5 \mathrm{H}), 8.38(\mathrm{~d}, J=9.2 \mathrm{~Hz}, 0.5 \mathrm{H})$, $8.24-8.18(\mathrm{~m}, 2 \mathrm{H}), 8.18-8.10(\mathrm{~m}, 2 \mathrm{H}), 8.09-7.99(\mathrm{~m}, 4 \mathrm{H}), 7.75-7.69(\mathrm{~m}, 2 \mathrm{H}), 7.50(\mathrm{tt}, J=$ 7.4, 1.2 Hz, 0.5H), $7.42-7.35(\mathrm{~m}, 1.5 \mathrm{H}), 7.33-7.27(\mathrm{~m}, 2 \mathrm{H}), 7.23-7.13(\mathrm{~m}, 1 \mathrm{H}), 7.10$ (td, $J$ $=6.8,1.4 \mathrm{~Hz}, 1 \mathrm{H}), 7.07-7.02(\mathrm{~m}, 1.5 \mathrm{H}), 6.97(\mathrm{dd}, J=6.8,1.5 \mathrm{~Hz}, 0.5 \mathrm{H}), 6.73(\mathrm{~s}, 1 \mathrm{H}), 6.44$ (br.s, $0.5 \mathrm{H}), 6.12$ (d, $J=2.8 \mathrm{~Hz}, 0.5 \mathrm{H}), 6.01$ (br.s, $0.5 \mathrm{H}), 5.69$ (d, $J=2.9 \mathrm{~Hz}, 0.5 \mathrm{H}$ ), 5.27 (s, 
$2 \mathrm{H}), 4.10(\mathrm{t}, J=6.2 \mathrm{~Hz}, 1 \mathrm{H}), 4.02-3.93(\mathrm{~m}, 2 \mathrm{H}), 3.88-3.69(\mathrm{~m}, 4.5 \mathrm{H}), 3.67-3.59(\mathrm{~m}$, $0.5 \mathrm{H}), 2.73-2.66(3 \mathrm{~s}, 6 \mathrm{H}), 2.35(\mathrm{~s}, 1.5 \mathrm{H}), 2.24(\mathrm{~s}, 1.5 \mathrm{H}), 2.22-2.11(\mathrm{~m}, 5.5 \mathrm{H}), 2.09(\mathrm{~s}$, $1.5 \mathrm{H}), 2.07-2.01(\mathrm{~m}, 2.5 \mathrm{H}), 1.86(\mathrm{~s}, 1.5 \mathrm{H}), 1.67-1.36(\mathrm{~m}, 15 \mathrm{H}), 1.17-0.87(\mathrm{~m}, 15 \mathrm{H}) .{ }^{13} \mathrm{C}$ NMR $\left(101 \mathrm{MHz}, \mathrm{CDCl}_{3}\right)(2$ conformers $) \delta=292.6\left(\mathrm{~d}, J_{\mathrm{P}-\mathrm{C}}=5.5 \mathrm{~Hz}\right), 292.5\left(\mathrm{~d}, J_{\mathrm{P}-\mathrm{C}}=5.8 \mathrm{~Hz}\right)$, $217.6\left(\mathrm{~d}, J_{\mathrm{P}-\mathrm{C}}=74 \mathrm{~Hz}\right), 217.3\left(\mathrm{~d}, J_{\mathrm{P}-\mathrm{C}}=73 \mathrm{~Hz}\right), 158.7,157.4,145.2,144.9,141.0,141.0$, $141.0,140.9$, 139.4, 139.1, 138.6, 138.5, 138.5, 138.0, 137.9, 137.1, 137.0, 137.0, 137.0, $136.9,136.9,136.6,135.6,132.6,131.7,131.7,131.4,131.4,131.4,131.0,130.9,130.9$, $130.0,129.5,129.5,129.3,129.2,129.1,129.0,128.9,128.7,128.2,128.2,127.9,127.8$, $127.6,127.5,127.5,127.5,127.2,127.1,127.0,127.0,126.6,126.4,126.1,126.1,125.4$, $125.4,125.3,125.3,125.1,124.9,124.6,124.6,123.6,123.6,116.2,116.0,114.6,114.5$, $114.4,112.0,71.9,71.9,67.3,67.2,64.8,64.2,53.6,52.8\left(\mathrm{~d}, J_{\mathrm{P}-\mathrm{C}}=3.3 \mathrm{~Hz}\right), 52.7\left(\mathrm{~d}, J_{\mathrm{P}-\mathrm{C}}=2.9\right.$ $\mathrm{Hz}), 52.3\left(\mathrm{~d}, J_{\mathrm{P}-\mathrm{C}}=1.7 \mathrm{~Hz}\right), 52.2\left(\mathrm{~d}, J_{\mathrm{P}-\mathrm{C}}=1.6 \mathrm{~Hz}\right), 35.7,33.0\left(\mathrm{~d}, J_{\mathrm{P}-\mathrm{C}}=16.6 \mathrm{~Hz}\right), 32.9\left(\mathrm{~d}, J_{\mathrm{P}-\mathrm{C}}\right.$ $=16.3 \mathrm{~Hz}$ ), 30.5, 30.1, 30.1, 29.5, 29.5, 29.4, 28.8, 28.0, 28.0, 27.9, 27.9, 27.8, 27.8, 27.7, 26.4, 25.6, 24.3, 21.3, 21.2, 20.9, 20.8, 20.4, 20.3, 19.3, 19.0, 18.9, 18.8. ${ }^{31} \mathrm{P}$ NMR (162 MHz, $\mathrm{CDCl}_{3}$ ) (2 conformers) $\delta=26.69,25.85$. HR-MS (MALDI): $\mathrm{m} / \mathrm{z}=1187.4900$, calcd. for $\mathrm{C}_{73} \mathrm{H}_{84} \mathrm{ClN}_{2} \mathrm{O}_{2} \mathrm{PRu}[\mathrm{M}-\mathrm{Cl}]^{+\bullet}: 1187.4924$ (2 ppm).

$\mathrm{N}$-(4-isopropoxy-3-vinylphenyl)-4-(pyren-1-yl)butanamide (8): In a dry round bottomed flask, 4-isopropoxy-3-vinylaniline hydrochloride[22] (500 mg, $2.34 \mathrm{mmol})$ was dissolved in $\mathrm{CH}_{2} \mathrm{Cl}_{2}(25 \mathrm{~mL})$ and deprotonated with pyridine $(208 \mu \mathrm{L}, 2.57 \mathrm{mmol})$. After 30 minutes under stirring, the organic phase was washed successively with deionized water and brine, dried over $\mathrm{MgSO}_{4}$ and filtered. The resulting solution was completed to $40 \mathrm{~mL}$ with $\mathrm{CH}_{2} \mathrm{Cl}_{2}$ then 4-(pyren-1-yl)butanoic acid (674.6 mg, $2.34 \mathrm{mmol})$, DCC (482.7 $\mathrm{mg}, 2.34 \mathrm{mmol}$ ) and DMAP (571.7 mg, $4.68 \mathrm{mmol}$ ) were successively added at $0{ }^{\circ} \mathrm{C}$. The mixture was stirred for $16 \mathrm{~h}$ at $\mathrm{rt}$ then treated with $\mathrm{HCl}(1 \mathrm{M}, 40 \mathrm{~mL})$ and extracted with $\mathrm{CH}_{2} \mathrm{Cl}_{2}$. The organic phase was washed with brine, dried over $\mathrm{MgSO}_{4}$, filtered and evaporated under reduced pressure. The crude product was purified by flash chromatography on silica gel $\left(\mathrm{CH}_{2} \mathrm{Cl}_{2}\right)$ giving $\mathbf{8}$ as a white powder $(772.1 \mathrm{mg}, 74 \%) . \mathrm{Mp}=162{ }^{\circ} \mathrm{C} .{ }^{1} \mathrm{H} \mathrm{NMR}\left(400 \mathrm{MHz}, \mathrm{CDCl}_{3}\right) \delta=8.29(\mathrm{~d}, J=$ $9.2 \mathrm{~Hz}, 1 \mathrm{H}), 8.18-8.14(\mathrm{~m}, 2 \mathrm{H}), 8.10(\mathrm{~d}, J=7.7 \mathrm{~Hz}, 1 \mathrm{H}), 8.08$ (d, $J=9.2 \mathrm{~Hz}, 1 \mathrm{H}), 8.02$ (s, 2H), $7.99(\mathrm{dd}, J=7.9,7.4 \mathrm{~Hz}, 1 \mathrm{H}), 7.86(\mathrm{~d}, J=7.8 \mathrm{~Hz}, 1 \mathrm{H}), 7.49$ (d, $J=2.7 \mathrm{~Hz}, 1 \mathrm{H}), 7.36$ (dd, $J=8.8,2.7 \mathrm{~Hz}, 1 \mathrm{H}), 7.05$ (br.s, $1 \mathrm{H}), 7.01$ (dd, $J=17.8,11.2 \mathrm{~Hz}, 1 \mathrm{H}), 6.80$ (d, $J=8.8 \mathrm{~Hz}$, $1 \mathrm{H}), 5.70$ (dd, $J=17.8,1.5 \mathrm{~Hz}, 1 \mathrm{H}), 5.24$ (dd, $J=11.1,1.4 \mathrm{~Hz}, 1 \mathrm{H}), 4.45$ (sept, $J=6.0 \mathrm{~Hz}$, $1 \mathrm{H}), 3.42(\mathrm{t}, J=7.3 \mathrm{~Hz}, 2 \mathrm{H}), 2.40-2.34(\mathrm{~m}, 2 \mathrm{H}), 2.33-2.24(\mathrm{~m}, 2 \mathrm{H}), 1.32(\mathrm{~d}, J=6.1 \mathrm{~Hz}$, $6 \mathrm{H}) .{ }^{13} \mathrm{C}$ NMR $\left(101 \mathrm{MHz}, \mathrm{CDCl}_{3}\right) \delta=170.9,152.1,135.8,131.6,131.5,131.1,131.0,130.1$, $128.9,128.5,127.6,127.6,127.5,126.9,126.0,125.2,125.1,125.1,124.9,123.5,121.1$, 118.6, 115.3, 114.7, 71.6, 36.8, 32.7, 27.3, 22.3. HR-MS (ESI): $\mathrm{m} / \mathrm{z}=470.2090$, calcd. for $\mathrm{C}_{31} \mathrm{H}_{29} \mathrm{NO}_{2} \mathrm{Na}[\mathrm{M}+\mathrm{Na}]^{+}: 470.2091$ (0 ppm).

$N$-(4-isopropoxy-3-(prop-1-en-1-yl)phenyl)-4-(pyren-1-yl)butanamide (L): In a dry round bottomed flask 4-isopropoxy-3-(prop-1-en-1-yl)aniline hydrochloride[8b] (92/8 E/Z mixture, $455.3 \mathrm{mg}, 2.0 \mathrm{mmol})$ was dissolved in $\mathrm{CH}_{2} \mathrm{Cl}_{2}(25 \mathrm{~mL})$ and deprotonated with pyridine (177 $\mu \mathrm{L}, 2.2 \mathrm{mmol}$ ). After 30 minutes under stirring the organic phase was washed successively with deionized water and brine, dried over $\mathrm{MgSO}_{4}$ and filtered. The resulting solution was completed to $40 \mathrm{~mL}$ with $\mathrm{CH}_{2} \mathrm{Cl}_{2}$ then 4-(pyren-1-yl)butanoic acid (576.7 mg, $2.0 \mathrm{mmol}$ ), DCC (412.7 mg, $2.0 \mathrm{mmol}$ ) and DMAP (488.7 mg, $4.00 \mathrm{mmol}$ ) were successively added at 0 ${ }^{\circ} \mathrm{C}$. The mixture was stirred for $16 \mathrm{~h}$ at $\mathrm{rt}$ then treated with $\mathrm{HCl}(1 \mathrm{M}, 40 \mathrm{~mL})$ and extracted 
with $\mathrm{CH}_{2} \mathrm{Cl}_{2}$. The organic phase was washed with brine, dried over $\mathrm{MgSO}_{4}$, filtered and evaporated under reduced pressure. The crude product was purified by flash chromatography on silica gel $\left(\mathrm{CH}_{2} \mathrm{Cl}_{2}\right)$ giving $\mathbf{L}$ as a tan powder (92/8 $\mathrm{E} / \mathrm{Z}$ mixture, $\left.751.1 \mathrm{mg}, 81 \%\right)$. $\mathrm{Mp}=$ $107{ }^{\circ} \mathrm{C} .{ }^{1} \mathrm{H}$ NMR $\left(400 \mathrm{MHz}, \mathrm{CDCl}_{3}, E\right.$ isomer $) \delta=8.31(\mathrm{~d}, J=9.2 \mathrm{~Hz}, 1 \mathrm{H}), 8.16(\mathrm{~d}, J=7.6$ $\mathrm{Hz}, 2 \mathrm{H}), 8.11(\mathrm{~d}, J=7.7 \mathrm{~Hz}, 1 \mathrm{H}), 8.09(\mathrm{~d}, J=9.1 \mathrm{~Hz}, 1 \mathrm{H}), 8.03(\mathrm{~s}, 2 \mathrm{H}), 7.99$ (dd, $J=8.0,7.2$ Hz, 1H), 7.87 (d, $J=7.8 \mathrm{~Hz}, 1 \mathrm{H}), 7.37-7.29$ (m, 2H), 6.98 (br.s, 1H), 6.83 (d, $J=8.6 \mathrm{~Hz}$, $1 \mathrm{H}), 6.50$ (br.dq, $J=11.6,1.9 \mathrm{~Hz}, 1 \mathrm{H}), 5.80$ (dq, $J=11.6,7.1 \mathrm{~Hz}, 1 \mathrm{H}), 4.43$ (sept, $J=6.0 \mathrm{~Hz}$, $1 \mathrm{H}), 3.45(\mathrm{t}, J=7.3 \mathrm{~Hz}, 2 \mathrm{H}), 2.43-2.36(\mathrm{~m}, 2 \mathrm{H}), 2.36-2.25(\mathrm{~m}, 2 \mathrm{H}), 1.84(\mathrm{dd}, J=7.1,1.9$ $\mathrm{Hz}, 3 \mathrm{H}), 1.31(\mathrm{~d}, J=6.0 \mathrm{~Hz}, 6 \mathrm{H}) \cdot{ }^{13} \mathrm{C} \mathrm{NMR}\left(101 \mathrm{MHz}, \mathrm{CDCl}_{3}\right) \delta=170.9,152.5,135.8$, $131.5,131.0,130.5,130.0,128.9,128.3,127.6$, 127.5, 127.4, 127.0, 126.8, 125.9, 125.2, $125.2,125.1,125.0,124.9,123.4,122.6,120.0,115.0,71.5,36.8,32.7,27.3,22.3$, 14.9. HRMS (ESI): $\mathrm{m} / \mathrm{z}=484.2245$, calcd. for $\mathrm{C}_{32} \mathrm{H}_{31} \mathrm{NO}_{2} \mathrm{Na}[\mathrm{M}+\mathrm{Na}]^{+}: 484.2247$ (0 ppm).

C1: In a Schlenk tube were placed under argon 7 (73.4 mg, $0.06 \mathrm{mmol}), 2,2,2$-trifluoro- $N$-(4isopropoxy-3-vinylphenyl)acetamide $(16.4 \mathrm{mg}, 0.06 \mathrm{mmol})$ and $\mathrm{CuCl}(6.5 \mathrm{mg}, 0.07 \mathrm{mmol})$, then $\mathrm{CH}_{2} \mathrm{Cl}_{2}(1.8 \mathrm{~mL})$ was added and the solution was heated at $35{ }^{\circ} \mathrm{C}$ for $16 \mathrm{~h}$ under stirring. The mixture was concentrated under reduced pressure then dissolved in acetone and filtered on celite bed. The crude was purified by flash chromatography on silica gel (pentane/AcOEt, 7:3 to 1:1). The solid obtained was precipitated from $\mathrm{CH}_{2} \mathrm{Cl}_{2}$ by the addition of pentane, giving $\mathbf{C 1}$ as a light green powder $(54.2 \mathrm{mg}, 90 \%) .{ }^{1} \mathrm{H} \mathrm{NMR}\left(400 \mathrm{MHz}, 55{ }^{\circ} \mathrm{C}, \mathrm{CDCl}_{3}\right) \delta=$ $16.41(\mathrm{~s}, 1 \mathrm{H}), 8.28(\mathrm{~d}, J=9.2 \mathrm{~Hz}, 1 \mathrm{H}), 8.17(\mathrm{~d}, J=7.6 \mathrm{~Hz}, 1 \mathrm{H}), 8.13(\mathrm{~d}, J=7.5 \mathrm{~Hz}, 1 \mathrm{H}), 8.06$ (d, $J=7.8 \mathrm{~Hz}, 1 \mathrm{H}), 8.02-7.90(\mathrm{~m}, 6 \mathrm{H}), 7.33$ (br.d, $J=8.7 \mathrm{~Hz}, 1 \mathrm{H}), 7.08$ (s, 2H), 7.02 (br.s, $1 \mathrm{H}$ ), 6.77 (s, 2H), 6.43 (br.d, $J=8.8 \mathrm{~Hz}, 1 \mathrm{H}$ ), 5.26 (s, 2H), 4.68 (sept, $J=6.1 \mathrm{~Hz}, 1 \mathrm{H}$ ), 4.23 $4.13(\mathrm{~m}, 6 \mathrm{H}), 3.94$ (br.t, $J=6.0 \mathrm{~Hz}, 2 \mathrm{H}), 2.51(\mathrm{~s}, 6 \mathrm{H}), 2.43$ and $2.42(2 \mathrm{~s}, 9 \mathrm{H}), 2.21$ (tt, $J \sim$ 6.0, 6.0 Hz, 2H), $1.21(\mathrm{~d}, J=6.1 \mathrm{~Hz}, 6 \mathrm{H}) .{ }^{13} \mathrm{C} \mathrm{NMR}\left(101 \mathrm{MHz}, \mathrm{CDCl}_{3}, 55{ }^{\circ} \mathrm{C}\right.$; partial : due to low solubility, uncomplete set of signals was obtained) $\delta=293.3,201.5,159.3,149.8$, 139.0 , 131.4, 131.2, 130.8, 129.8, 129.8, 129.7, 129.4, 129.4, 127.9, 127.4, 127.3, 127.2, $125.8,125.5,125.0,124.9,124.7,124.5,123.1,120.8,114.9,114.5,112.6,75.6,71.7,67.1$, 65.4, 51.7, 51.5, 29.5, 21.2, 20.9, 19.5 (br.m). ${ }^{19} \mathrm{~F} \mathrm{NMR}\left(376 \mathrm{MHz}, \mathrm{CDCl}_{3}\right) \delta=-75.5 . \mathrm{HR}-\mathrm{MS}$ (ESI): $\mathrm{m} / \mathrm{z}=1010.2230$, calcd. for $\mathrm{C}_{52} \mathrm{H}_{51} \mathrm{Cl}_{2} \mathrm{~F}_{3} \mathrm{~N}_{3} \mathrm{O}_{4} \mathrm{Ru}[\mathrm{M}-\mathrm{H}]^{-}: 1010.2252$ (2 ppm). Anal. Calcd for $\mathrm{C}_{52} \mathrm{H}_{52} \mathrm{Cl}_{2} \mathrm{~F}_{3} \mathrm{~N}_{3} \mathrm{O}_{4} \mathrm{Ru}$ : C, 61.72; H, 5.18; N, 4.15. Found: C, 61.93; H, 5.27; N, 4.23.

C2: A Schenk tube was charged with (SIPr)RuCl $2\left(\mathrm{PPh}_{3}\right)$ (Indenylidene) (101.5 mg, 0.10 $\mathrm{mmol})$ and compound $8(44.8 \mathrm{mg}, 0.10 \mathrm{mmol})$. The powders were placed under argon, dissolved in dry and degazed $\mathrm{CH}_{2} \mathrm{Cl}_{2}(2.7 \mathrm{~mL})$ and heated in an oil bath at $40{ }^{\circ} \mathrm{C}$ for $24 \mathrm{~h}$. The heterogeneous mixture was then concentrated by half under reduced pressure, then distilled $\mathrm{Et}_{2} \mathrm{O}(15 \mathrm{~mL})$ was added whereupon a green powder precipitates. The filtrate was taken out by the means of a filtering cannula and the solid washed with $\mathrm{Et}_{2} \mathrm{O}$ until the liquid became colorless. The solid was dried under vacuum to afford $\mathbf{C 2}$ as a light green powder $(59.4 \mathrm{mg}$, $60 \%$ ). ${ }^{1} \mathrm{H}$ NMR (400 MHz, $\left.\mathrm{CD}_{2} \mathrm{Cl}_{2}\right) \delta=16.27(\mathrm{~s}, 1 \mathrm{H}), 8.37(\mathrm{~d}, J=9.2 \mathrm{~Hz}, 1 \mathrm{H}), 8.24-8.12$ $(\mathrm{m}, 4 \mathrm{H}), 8.10-8.05(\mathrm{~m}, 2 \mathrm{H}), 8.02(\mathrm{t}, J=7.6 \mathrm{~Hz}, 1 \mathrm{H}), 7.92(\mathrm{~d}, J=7.8 \mathrm{~Hz}, 1 \mathrm{H}), 7.78$ (dd, $J=$ 8.8, 2.6 Hz, 1H), 7.53 (t, $J=7.7 \mathrm{~Hz}, 2 \mathrm{H}), 7.38$ (d, $J=7.8 \mathrm{~Hz}, 4 \mathrm{H}), 7.09$ (s, 1H), 6.83 (d, $J=$ $2.6 \mathrm{~Hz}, 1 \mathrm{H}), 6.75(\mathrm{~d}, J=8.9 \mathrm{~Hz}, 1 \mathrm{H}), 4.85$ (sept, $J=6.0 \mathrm{~Hz}, 1 \mathrm{H}), 4.17$ (s, 4H), 3.57 (sept, $J=$ $6.6 \mathrm{~Hz}, 4 \mathrm{H}), 3.45(\mathrm{t}, J=7.6 \mathrm{~Hz}, 2 \mathrm{H}), 2.43(\mathrm{t}, J=7.3 \mathrm{~Hz}, 2 \mathrm{H}), 2.27(\mathrm{tt}, J \sim 7.5, \sim 7.5 \mathrm{~Hz}, 2 \mathrm{H})$, $1.31(\mathrm{~d}, J=6.1 \mathrm{~Hz}, 6 \mathrm{H}), 1.28-1.17(\mathrm{~m}, 24 \mathrm{H}) .{ }^{13} \mathrm{C} \mathrm{NMR}\left(101 \mathrm{MHz}, \mathrm{CD}_{2} \mathrm{Cl}_{2}\right) \delta=213.2$, $171.1,149.8,149.2,144.4,137.3,136.7,133.5,132.0,131.5,130.5,130.2,129.4,128.0$, 
$128.0,127.9,127.2,126.5,125.6,125.4,125.4,125.3,124.8,124.0,121.4,113.6,113.4,75.8$, 55.2, 37.2, 33.2, 29.3, 27.7, 26.9, 23.7, 22.0. HR-MS (ESI): $\mathrm{m} / \mathrm{z}=995.3502$, calcd. for $\mathrm{C}_{57} \mathrm{H}_{65} \mathrm{~N}_{3} \mathrm{O}_{2} \mathrm{Cl}_{2} \mathrm{Ru}[\mathrm{M}]^{+} \cdot 995.34918$ (1 ppm). Anal. Calcd for $\mathrm{C}_{57} \mathrm{H}_{65} \mathrm{~N}_{3} \mathrm{O}_{2} \mathrm{Cl}_{2} \mathrm{Ru}: \mathrm{C}, 68.73$; H, 6.58; N, 4.22. Found: C, 68.35; H, 6.67; N, 3.99.

C3: In a Schlenk tube were placed under argon Ru complex 7 (73.4 mg, 0.06 mmol), $\mathrm{N}$-(4isopropoxy-3-vinylphenyl)-4-(pyren-1-yl)butanamide 8 (26.9 mg, $0.06 \mathrm{mmol})$ and $\mathrm{CuCl}$ (6.5 $\mathrm{mg}, 0.07 \mathrm{mmol})$, then $\mathrm{CH}_{2} \mathrm{Cl}_{2}(1.8 \mathrm{~mL})$ was added and the solution was heated at $35{ }^{\circ} \mathrm{C}$ overnight under stirring. The mixture was concentrated under reduced pressure then dissolved in acetone and filtered on a celite bed. The crude product was purified by flash chromatography on silica gel (pentane/AcOEt, 7:3 to 1:2). The solid was precipitated from $\mathrm{CH}_{2} \mathrm{Cl}_{2}$ by the addition of pentane to afford $\mathbf{C 3}$ as a light green powder $(67.2 \mathrm{mg}, 94 \%) .{ }^{1} \mathrm{H}$ NMR $\left(400 \mathrm{MHz}, \mathrm{CDCl}_{3}\right) \delta=16.47(\mathrm{~s}, 1 \mathrm{H}), 8.26(\mathrm{~d}, J=9.3 \mathrm{~Hz}, 1 \mathrm{H}), 8.22$ (br.d, $J \sim 9 \mathrm{~Hz}$, $1 \mathrm{H}), 8.18-8.05(\mathrm{~m}, 6 \mathrm{H}), 8.05-7.89(\mathrm{~m}, 8 \mathrm{H}), 7.87-7.79(\mathrm{~m}, 2 \mathrm{H}), 7.47$ (br.s, 1H), 7.07 (s, 2H), 6.87 (br.s, 2H), 6.72 (s, 2H), 6.50 (d, $J=8.9 \mathrm{~Hz}, 1 \mathrm{H}$ ), 5.08 (br.s, 2H), 4.72 (sept, $J=6.0$ $\mathrm{Hz}, 1 \mathrm{H}), 4.19-4.11(\mathrm{~m}, 4 \mathrm{H}), 4.08(\mathrm{t}, J=6.2 \mathrm{~Hz}, 2 \mathrm{H}), 3.73-3.62(\mathrm{~m}, 2 \mathrm{H}), 3.41-3.31(\mathrm{~m}$, 2H), 2.51 (s, 6H), 2.42 (s, 6H), 2.40 (s, 3H), 2.18 (br.s, 4H), $2.07-1.98$ (m, 2H), 1.23 (d, $J=$ $6.1 \mathrm{~Hz}, 6 \mathrm{H}) .{ }^{13} \mathrm{C} \mathrm{NMR}\left(101 \mathrm{MHz}, \mathrm{CDCl}_{3}\right) \delta=295.4,212.3,159.3,145.4,139.1,136.1,132.8$, $131.7,131.6,131.4,131.2,131.0,130.3,129.6,129.2,128.2,127.7,127.6,127.6,127.5$, $127.2,127.0,126.1,126.0,125.8,125.4,125.3,125.2,125.1,125.0,124.9,124.6,123.6$, 123.3, 115.1, 114.3, 112.8, 75.4, 71.8, 67.2, 65.5, 52.0, 51.7, 36.5 (br.), 32.7, 29.8, 27.3, 21.4, 21.2, 19.8 (br.). HR-MS (ESI): $\mathrm{m} / \mathrm{z}=1185.3559$, calcd. for $\mathrm{C}_{70} \mathrm{H}_{67} \mathrm{~N}_{3} \mathrm{O}_{4} \mathrm{Cl}_{2} \mathrm{Ru}[\mathrm{M}]^{+}$: 1185.3547 (1 ppm). Anal. Calcd for $\mathrm{C}_{70} \mathrm{H}_{67} \mathrm{~N}_{3} \mathrm{O}_{4} \mathrm{Cl}_{2} \mathrm{Ru}$ : C, 70.87; H, 5.69; N, 3.54. Found: C, $70.72 ; \mathrm{H}, 5.68 ; \mathrm{N}, 3.41$.

4.3. General procedure for homogeneous catalysis: Substrate $(0.1 \mathrm{mmol})$ and mesitylene $(0.1 \mathrm{mmol}, 12.0 \mathrm{mg})$ were placed under argon in an NMR tube sealed with a septum. The tube was then added with the desired deuterated and degazed solvent $(500 \mu \mathrm{L})$, and a first ${ }^{1} \mathrm{H}$ NMR experiment was run at the desired temperature to serve as $t_{0}$ reference. An aliquot $(25 \mu \mathrm{L}$, $0.01 \mu \mathrm{mol}$ ) from a $4 \mu \mathrm{mol} / 10 \mathrm{~mL}$ solution of complex in $\mathrm{CH}_{2} \mathrm{Cl}_{2}$ was then injected in the NMR tube which was put back in the spectrometer after shacking. The progress of the reaction was monitored by iterated ${ }^{1} \mathrm{H}$ NMR experiments and yields calculated against the signal of mesitylene.

4.4. General procedure for complex immobilization on rGO und UV-Vis analyses: $10 \mathrm{mg}$ of catalyst were dissolved in $10 \mathrm{~mL}$ of DCM delivering a homogeneous green solution from which $1 \mathrm{~mL}$ was introduced in a schlenk tube. $\mathrm{rGO}$ (20 or $40 \mathrm{mg}$ ) was introduced into the schlenk and the resulting heterogeneous mixture was stirred at room temperature for the specified time. $15 \mu \mathrm{L}$ of the corresponding solution were removed by a syringe at regular time intervals, diluted in $1 \mathrm{~mL}$ DCM and analyzed by UV-visible spectrometry. After total immobilization, the supported complexes were isolated as black powders by simple filtration, washed twice with DCM and dried under reduced pressure before use in catalysis.

4.5. General procedure for complex and ligand $L$ immobilization on rGO and UV-Vis analyses: the $\mathrm{Ru}$ catalyst was immobilized onto $40 \mathrm{mg} \mathrm{rGO}$ following the procedure 
described above. $20 \mathrm{mg}$ of ligand $\mathbf{L}$ were dissolved in $10 \mathrm{~mL}$ of DCM from which $1 \mathrm{~mL}$ was introduced in the schlenk tube containing the supported catalyst and the resulting heterogeneous mixture was stirred at room temperature. $15 \mu \mathrm{L}$ of the corresponding solution were removed by a syringe at regular time intervals, diluted in $1 \mathrm{~mL} \mathrm{DCM}$ and analyzed by UV-visible spectrometry. After total immobilization of the ligand, the supported catalystligand on rGO (black powder) was isolated by simple filtration, washed twice with DCM and dried under reduced pressure.

4.6. General procedure for complex immobilization on graphene: graphene (40 $\mathrm{mg}$ ) was put under argon and dispersed in $\mathrm{CH}_{2} \mathrm{Cl}_{2}(500 \mu \mathrm{L})$. An aliquot $(0.001 \mathrm{mmol}, 100 \mu \mathrm{L})$ from a solution of $\mathrm{Ru}$ complex $(0.01 \mathrm{mmol})$ in $\mathrm{CH}_{2} \mathrm{Cl}_{2}(1 \mathrm{~mL})$ was then injected in the Schlenk tube and the heterogeneous mixture agitated for $6 \mathrm{~h}$. The supported complex was recovered by centrifugation (8000 g, 5 min), washed 2 times with $\mathrm{CH}_{2} \mathrm{Cl}_{2}(500 \mu \mathrm{L})$, dried under vacuum and directly used in catalysis.

\subsection{General procedure for heterogeneous catalysis using immobilized complex on rGO:} The rGO-supported complex (20 or $40 \mathrm{mg}$; $0.001 \mathrm{mmol}$ of $\mathrm{Ru}$ complex) was placed in a Schlenk tube under argon. A solution of DEDAM $(24 \mu \mathrm{L}, 0.1 \mathrm{mmol})$ in 0.5 or $1 \mathrm{~mL}$ of DCM was then added and the reaction was mixed. Samples were withdrawn by a syringe at regular time intervals, quenched by the addition of a few drops of ethyl vinyl ether, and analyzed by gas chromatography (see SI for details). At the end of the reaction, after each run, product recovery was realized by filtration at room temperature. The catalytic material was washed once with $1 \mathrm{~mL}$ of DCM and a new catalytic run was then performed in the same reaction vessel. Exactly the same procedure was performed in the case of use of $\mathbf{C 2} / \mathbf{L} @ \mathrm{rGO}$ as supported catalyst.

4.8. General procedure for heterogeneous catalysis using $\mathbf{C x} @$ graphene: To the supported complex placed in a hemolysis tube under argon and dispersed in solvent $(500 \mu \mathrm{L})$ were added DEDAM $(0.1 \mathrm{mmol}, 24 \mu \mathrm{L})$ and mesitylene $(0.1 \mathrm{mmol}, 12 \mu \mathrm{L})$. The tube was then placed in an oil bath heated at the desired temperature under vigorous stirring. Conversion was determined by ${ }^{1} \mathrm{H}$ NMR analysis against mesitylene from a partially concentrated aliquot. At the end of the reaction the supported complex was recovered by centrifugation ( $8000 \mathrm{~g}, 5 \mathrm{~min})$ and washed 3 times with solvent $(500 \mu \mathrm{L})$.

\section{Acknowledgments}

This work was supported by the Agence Nationale de la Recherche (ANR) (ANR-12-CD2I0002 Cflow-OM), the "Région Bretagne" [SAD 2014 - GRAPH-Ru (8734)], the Ministère de la Recherche et de la Technologie, and the Centre National de la Recherche Scientifique (CNRS). Oméga Cat System is warmly thanked for a generous gift of ruthenium precatalysts and ligand $\mathbf{L}$. 


\section{References}

[1] For selected comprehensive reviews on olefin metathesis, see: (a) Olefin Metathesis: Theory and Practice (Ed.: K. Grela), John Wiley \& Sons Inc., Hoboken, (2014); (b) Handbook of Metathesis, $2^{\text {nd }}$ edition (Eds.: R. H. Grubbs, A. G. Wenzel, D. J. O'Leary, E. Khosravi), Wiley-VCH, Weinheim, (2015); (c) G. C. Vougioukalakis, R. H. Grubbs, Chem. Rev. 110 (2010) 1746-1787; (d) S. P. Nolan, H. Clavier, Chem. Soc. Rev. 39 (2010) 33053316; (e) S. Khota, M. K. Dipak, Tetrahedron 68 (2012) 397-442; (f) F. B. Hamad, T. Sun, S. Xiao, F. Verpoort, Coord. Chem. Rev. 257 (2013) 2274-2292.

[2] For recent reviews dealing with the application of olefin metathesis in total synthesis see: (a) J. Cossy, Olefin Metathesis: Theory and Practice (Ed.: K. Grela), John Wiley \& Sons Inc., Hoboken, (2014), p. 287-309; (b) A. Fürstner, Chem. Commun. 47 (2011) 6505-6511.

[3] H. Clavier, K. Grela, A. Kirschning, M. Mauduit, S. P. Nolan, Angew. Chem. Int. Ed. 46 (2007) 6786-6801.

[4] For example, see: (a) X. Bantreil, R. A. M. Randall, A. M. Z. Slawin, S. P. Nolan, Organometallics 29 (2010) 3007-3011; (b) V. Sashuk, L. H. Peeck, H. Plenio, Chem. Eur. J. 16 (2010), 3983-3993; (c) K. M. Kuhn, T. M. Champagne, S. H. Hong, W.-H. Wei, A. Nickel, C. W. Lee, S. C. Virgil, R. H. Grubbs, R. L. Pederson, Org. Lett. 12 (2010) 984-987.

[5] For recent reviews dealing with the immobilization of olefin metathesis catalysts, see: (a) M. R. Buchmeiser, Olefin Metathesis: Theory and Practice (Ed.: K. Grela), John Wiley \& Sons Inc., Hoboken, (2014), p. 495-514; (b) M. R. Buchmeiser, Chem. Rev. 109 (2009) 303321; For a recent review dealing with the introduction of ionic tags on olefin metathesis catalysts, see: (c) P. Queval, M. Rouen, A.-C. Gaumont, I. Dez, O. Baslé, M. Mauduit, Olefin Metathesis: Theory and Practice (Ed.: K. Grela), John Wiley \& Sons Inc., Hoboken, (2014), p. 547-558; For selected publications on supported Hoveyda-type precatalysts, see: (d) M. R. Buchmeiser, New J. Chem. 28 (2004) 549-557; (e) C. Copéret, J.-M. Basset, Adv. Synth. Catal. 349 (2007) 78-92; (f) H. Yang, Z. Ma, Y. Wang, Y. Wang, L. Fang, Chem. Commun. 46 (2010) 8659-8661; (g) B. Marciniec, S. Rogalski, M. J. Potrzebowski, C. Pietrazuk, ChemCatChem 3 (2011) 904-910.

[6] (a) D. P. Allen, M. M. Van Wingerden, R. H. Grubbs, Org. Lett. 11 (2009) 1261-1264; (b) I. Karamé, M. Boualleg, J.-M. Camus, T. K. Maishal, J. Alauzun, J.-M. Basset, C. Copéret, R. J. P. Corriu, E. Jeanneau, A. Mehdi, C. Reyé, L. Veyre, C. Thieuleux, Chem. Eur. J. 15 (2009) 11820-11823; (c) A. Monge-Marcet, R. Pleixats, X. Cattoën, M. W. Chi Man, Tetrahedron 69 (2013) 341-348; (d) J.-E. Jee, J. J. L. Cheong, J. Lim, C. Chen, S. H. Hong, S. S. Lee, J. Org. Chem. 78 (2013) 3048-3056; (e) J. L. Cheong, D. Wong, S.-G. Lee, J. Lim, S. S. Lee, Chem. Commun. 51 (2015) 1042-1045.

[7] (a) R. Duque, E. Öchsner, H. Clavier, F. Caijo, S. P. Nolan, M. Mauduit, D. J. ColeHamilton, Green Chem. 13 (2011) 1187-1195; (b) K. Skowerski, C. Wierzbicka, G. Szczepaniak, Ł. Gulajski, M. Bieniek, K. Grela, Green Chem. 14 (2012) 3264-3268; (c) M. Kluciar, K. Grela, M. Mauduit, Dalton Trans. 42 (2013) 7354-7358.

[8] (a) P.Sledz, M. Mauduit, K. Grela, Chem. Soc. Rev. 37 (2008) 2433-2442; (b) E. Borré, M. Rouen, I. Laurent, M. Magrez, F. Caijo, C. Crévisy, W. Solodenko, L. Toupet, R. Frankfurter, C. Vogt, A. Kirschning, M. Mauduit, Chem. Eur. J. 18 (2012) 16369-16382; (c) J. Pastva, K. Skowerski, S. J. Czarnocki, N. Žilková, J. Čejka, Z. Bastl, H. Balcar, ACS Catal. 4 (2014) 3227-3236. 
[9] (a) W. Solodenko, A. Doppiu, R. Frankfurter, C. Vogt, A. Kirschning, Aust. J. Chem. 66 (2013) 183-191; (b) H. Nasrallah, D. Dragoe, C. Magnier, C. Crévisy, M. Mauduit, E. Schulz, ChemCatChem 7 (2015) 2493-2500.

[10] H. Nasrallah, A. Pagnoux, D. Didier, C. Magnier, L. Toupet, R. Guillot, C. Crévisy, M. Mauduit, E. Schulz, Eur. J. Org. Chem. (2014) 7781-7787.

[11] A. Schaetz, M. Zeltner, W. J. Stark, ACS Catal. 2 (2012) 1267-1284.

[12] L. Xing, J. H. Xie, Y. S. Chen, L. X. Wang, Q. L. Zhou, Adv. Synth. Catal. 350 (2008) 1013-1016.

[13] D. Didier, E. Schulz, Tetrahedron: Asymmetry 24 (2013) 769-775.

[14] C. Vriamont, M. Devillers, O. Riant, S. Hermans, Chem. Eur. J. 19 (2013) 12009-12017.

[15] G. Liu, B. Wu,J. Zhang, X. Wang, M. Shao, J. Wang, Inorg. Chem. 48 (2009) 23832390.

[16] Q. M. Kainz, O. Reiser, Acc. Chem. Res. 47 (2014) 667-677.

[17] M. Keller, V. Collière, O. Reiser, A. M. Caminade, J. P . Majoral, A. Ouali, Angew. Chem. Int. Ed. 52 (2013) 3626-3629.

[18] (a) S. Sabater, J. A. Mata, E. Peris, ACS Catal. 4 (2014) 2038-2047; (b) S. Sabater, J. A. Mata, E. Peris, Organometallics 34 (2015) 1186-1190.

[19] For the first report about the release-return ("boomerang") mechanism, see: (a) J. S. Kingsbury, J. P. A. Harrity, P. J. Bonitatebus, A. H. Hoveyda, J. Am. Chem. Soc. 121 (1999) 791-799; for recent papers dealing with the boomerang mechanism: see (b) J. S. Kingsbury, A. H. Hoveyda, J. Am. Chem. Soc. 127 (2005) 4510-4517; (c) M. Bieniek, A. Michrowska, D. L. Usanov, K. Grela, Chem. Eur. J. 14 (2008) 806-818; (d) T. Vorfalt, K J. Wannowius, V. Thiel, H. Plenio, Chem. Eur. J. 16 (2010) 12312-12315; (e) T. Vorfalt, K J. Wannowius, H. Plenio, Angew. Chem. Int. Ed. 49 (2010) 5533-5536; (f) V. Thiel, M. Hendann, K.- J. Wannowius, H. Plenio J. Am. Chem. Soc. 134 (2012) 1104-1114; (g) J. M. Bates, J. A. M. Lummiss, G. A. Bailey, D. E. Fogg, ACS. Catal. 4 (2014) 2387-2394.

[20] H. Clavier, F. Caijo, E. Borré, D. Rix, F. Boeda, S. P. Nolan, M. Mauduit Eur. J. Org. Chem. (2009) 4254-4265.

[21] J. P. Wolf, S. L. Buchwald, J. Org. Chem. 65 (2000) 1145-1157.

[22] M. Rouen, P. Queval, L. Falivene, J. Allard, L. Toupet, C. Crévisy, F. Caijo, O. Baslé, L. Cavallo, M. Mauduit, Chem. Eur. J. 20 (2014) 13716-13721.

[23] D. Rix, F. Caijo, I. Laurent, F. Boeda, H. Clavier, S. P. Nolan, M. Mauduit, J. Org. Chem. 73 (2008) 4225-4228.

[24] D. J. Nelson, P. Queval, M. Rouen, M. Magrez, L. Toupet, F. Caijo, E. Borré, I. laurent, C. Crévisy, O. Baslé, M. Mauduit, J. M. Percy, ACS Catal. 3 (2013) 259-264.

[25] A supplementary experiment has been conducted using $\mathbf{C 2}$ at $60^{\circ} \mathrm{C}$ for four consecutive runs. After 30 minutes reaction under these conditions, an important decrease in the conversion value could be noticed in the fourth run since it reached only $52 \%$ (75\% overnight).

[26] G. Szczepaniak, K. Kosinski, K. Grela, Green Chem. 16 (2014) 4474-4492.

[27] S. Hübner, J. G. de Vries, V. Farina, Adv. Synth. Catal. 358 (2016) 3-25.

[28] (a) H. Clavier, N. Audic, J.-C. Guillemin, M. Mauduit, J. Organomet. Chem. 690 (2005) 3585-3599; (b) see ref 6e 
[29] D. R. Dreyer, S. Park, C. W. Bielawski, R. S. Ruoff, Chem. Soc. Rev. 39 (2010) 228240.

[30] Similar experiments were undertaken with complexes $\mathbf{C 1}$ and $\mathbf{C 3}$, but far more disappointing results were obtained.

[31] H. Clavier, S. P. Nolan, Chem. Eur. J. 13 (2007) 8029-8036.

[32] C. M. So, S. Kume, T. Hayashi, J. Am. Chem. Soc. 135 (2013) 10990-10993.

[33] A. Paczal, A. C. Bényei, A. Kotschy J. Org. Chem. 71 (2006) 5969-5979. 


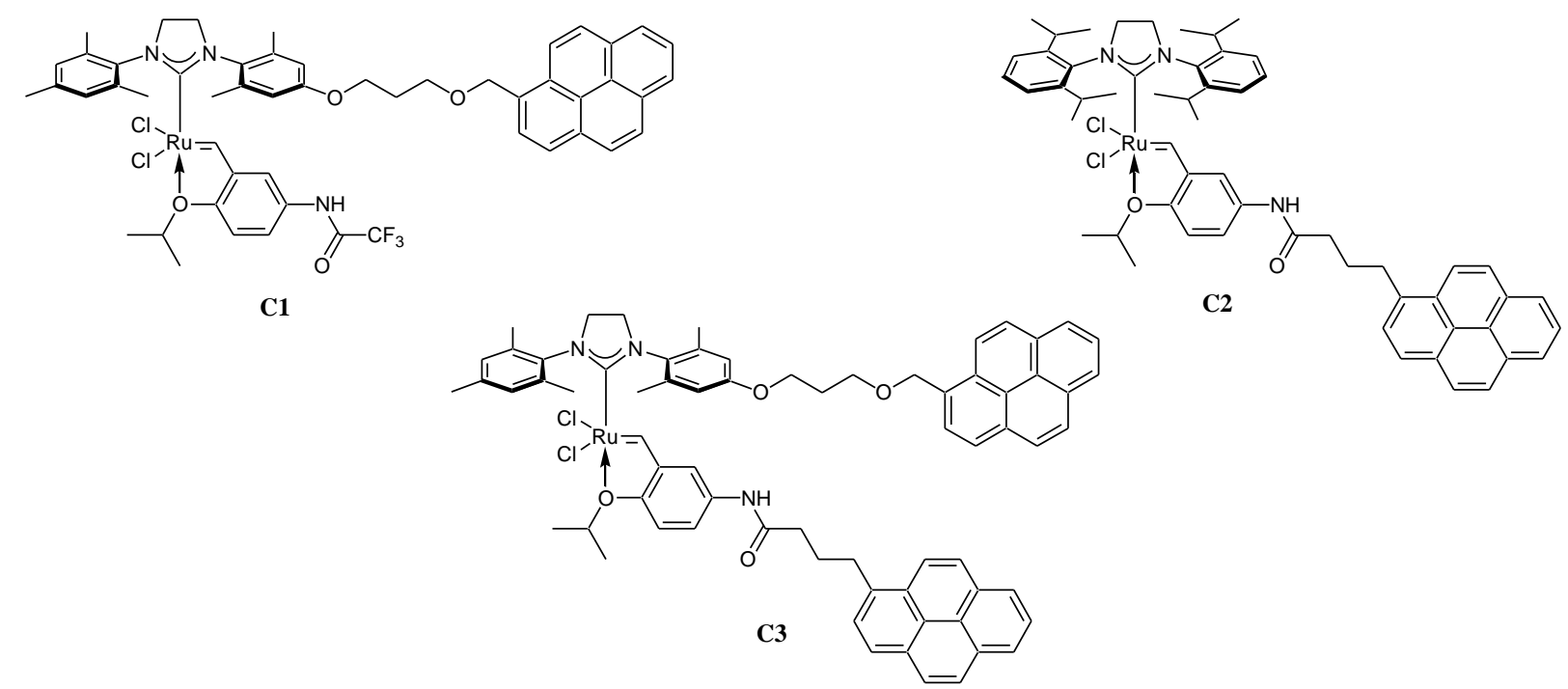

Figure 1. Pyrene-tagged Ru complexes C1, C2 and C3. 


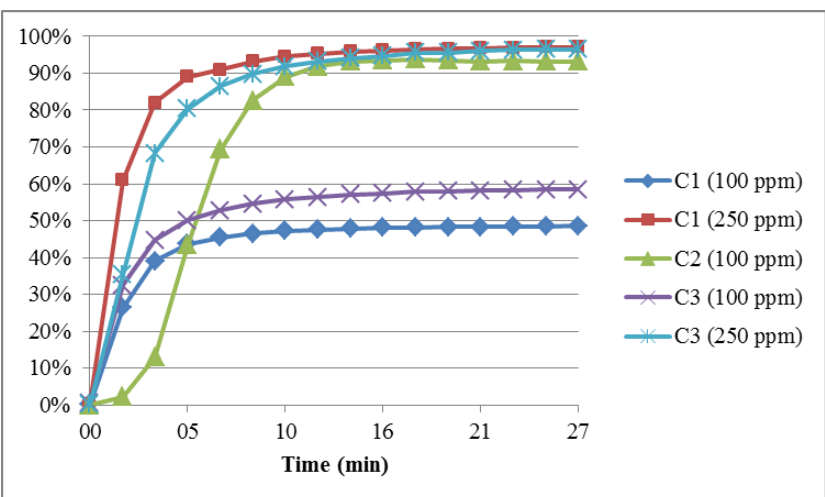

Figure 2. Kinetic profiles of the DEDAM metathesis (eq. 1, Scheme 3) by using precatalysts C1, C2 and $\mathbf{C 3}$ ([DEDAM] $=0.2 \mathrm{M}$, toluene- $\mathrm{D}_{8}, 60{ }^{\circ} \mathrm{C}$, conversion determined by NMR ${ }^{1} \mathrm{H}$ spectroscopy using mesitylene as internal standard). 


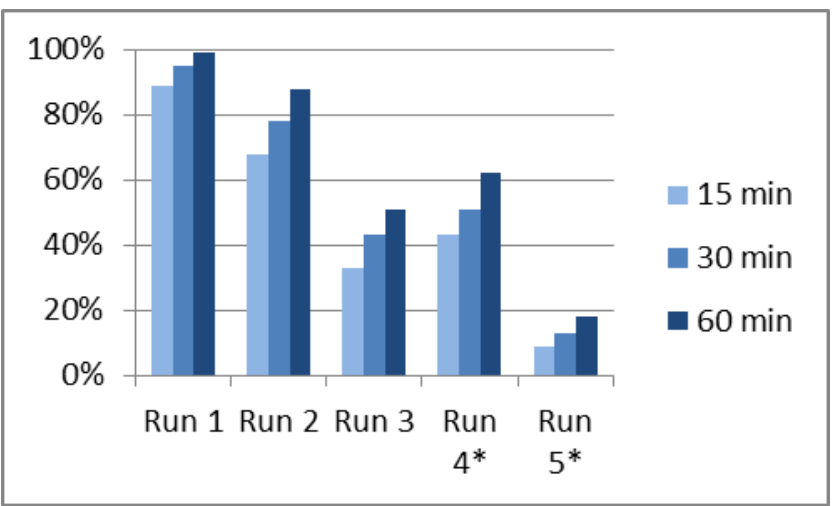

Figure 3. Conversion profiles of the DEDAM metathesis (eq. 1) by using immobilized precatalyst $\mathbf{C 1} @ \mathrm{rGO}: 50^{\circ} \mathrm{C}$, [DEDAM] $0.1 \mathrm{M}$ in toluene, $1 \mathrm{~mol} \% \mathrm{Ru}$ (*Reaction at $70{ }^{\circ} \mathrm{C}$ ). 


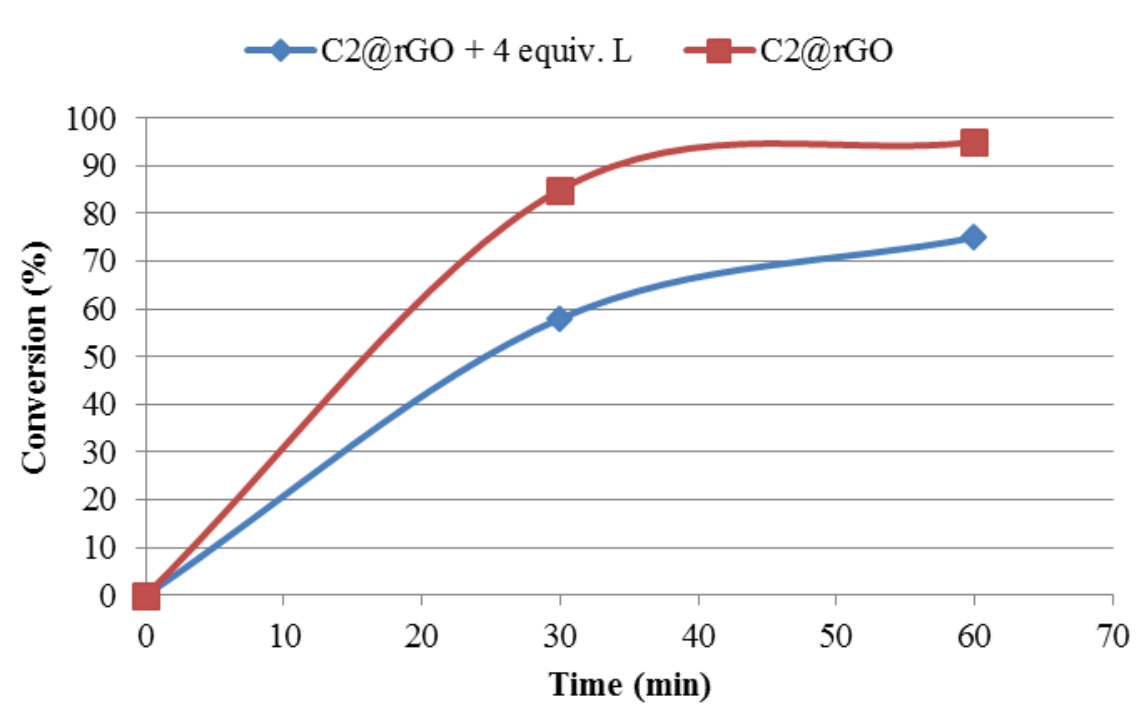

Figure 4. Kinetic profiles of the DEDAM metathesis (eq. 1) by using C2@rGO and C2@ $\mathrm{rGO}+4$ equiv. L $([\mathrm{DEDAM}]=0.1 \mathrm{M})$. 

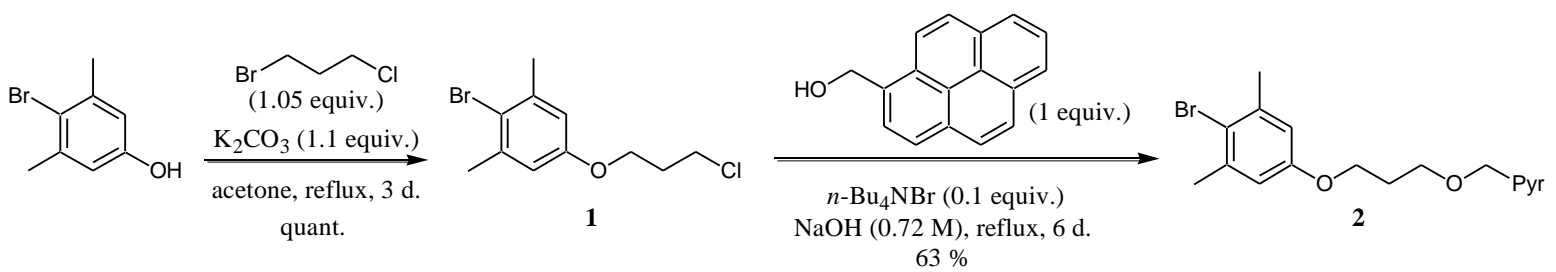

1) $N$-Boc-Gly (1 equiv.)

$\mathrm{N}$-methylmorpholine (1 equiv.)

$i-\mathrm{BuCO}_{2} \mathrm{Cl}$ (1 equiv.)

THF, $0{ }^{\circ} \mathrm{C}$ to rt., $5 \mathrm{~h}$

2) $\mathrm{HCl}$ ( 10 equiv.)

$\mathrm{MeOH}, 0{ }^{\circ} \mathrm{C}$ to rt., $14 \mathrm{~h}$
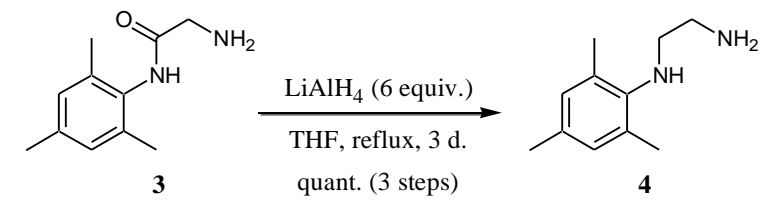

$\mathrm{Pd}(\mathrm{OAc})_{2}(8 \mathrm{~mol} \%)$

Binap (8 mol\%)

$2+4 \underset{\text { toluene, } 100{ }^{\circ} \mathrm{C} \text {, overnight }}{\stackrel{t \text {-BuONa }(1.3 \text { equiv. })}{\longrightarrow}}$

$81 \%$

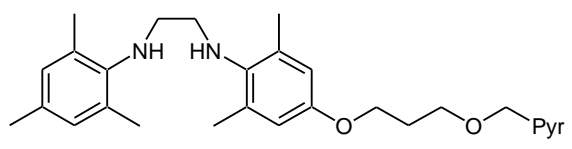

5

1) $\mathrm{HCl}$ ( 1 equiv.), $\mathrm{Et}_{2} \mathrm{O}, 10 \mathrm{~min}$.

$\underset{\text { 3) } \mathrm{KBF}_{4} \text { (2 equiv.), } \mathrm{CH}_{2} \mathrm{Cl}_{2}, 4 \mathrm{~h}}{\longrightarrow}$

$80 \%$<smiles>Cc1cc(C)c(N2CCN(c3c(C)cc(OCCCOCC(=O)c4ccccc4)cc3C)C2)c(C)c1</smiles>

6

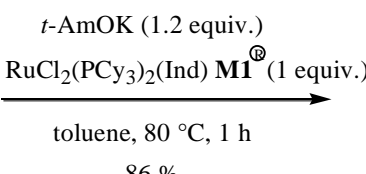

$86 \%$

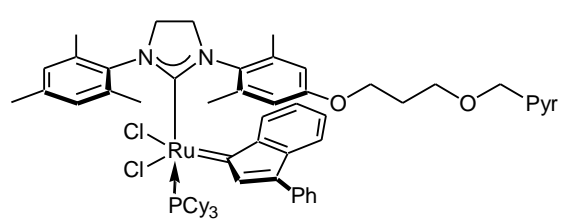

7

Scheme 1. Synthesis of imidazolidinium salt 6 and $\mathrm{Ru}$ complex $7(\mathrm{Pyr}=$ pyrene, Ind $=$ indenylidene). 

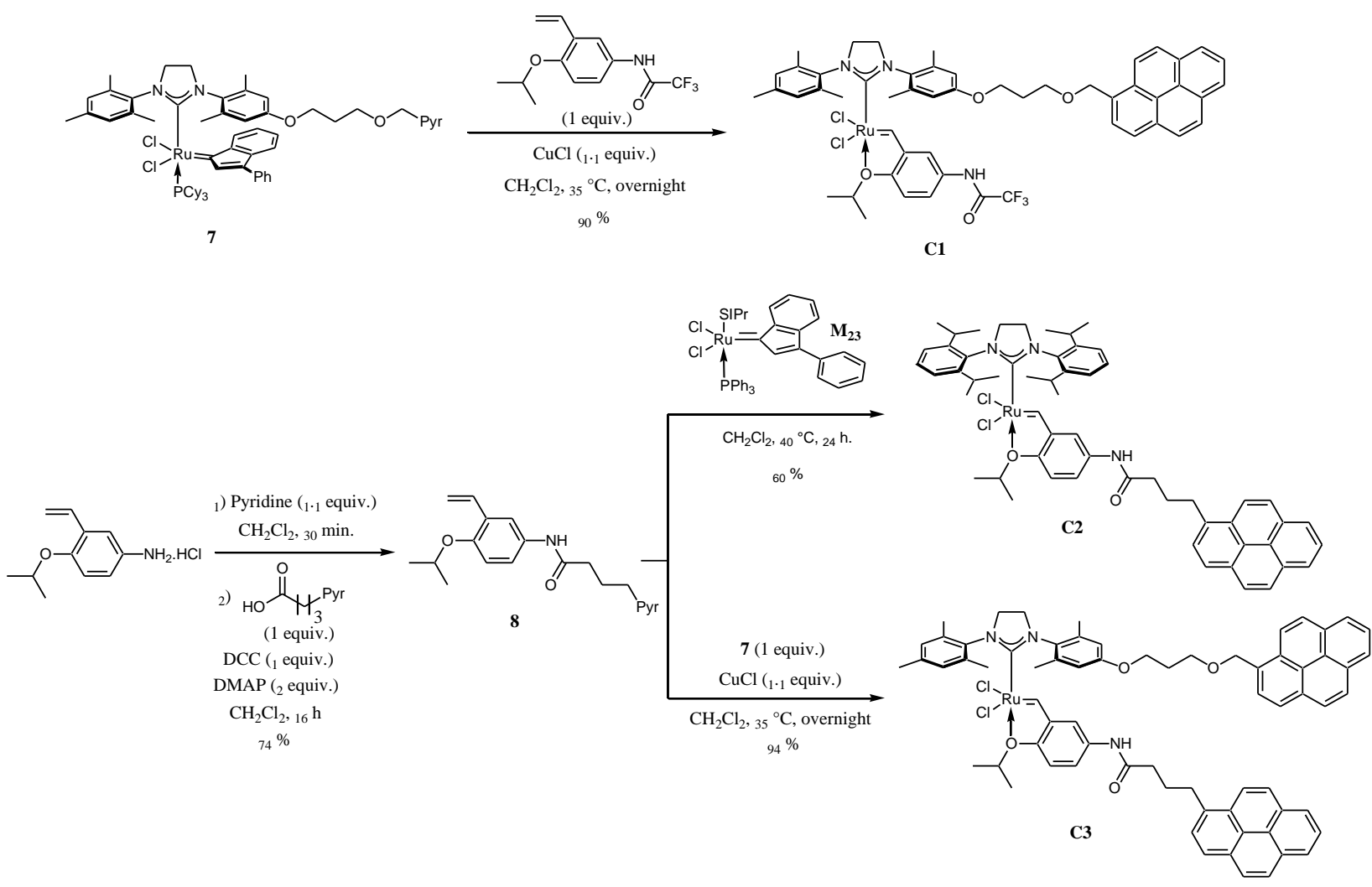

Scheme 2. Synthesis of pyrene-tagged Ru complexes C1, C2 and C3. 
<smiles>C=CCC(CC=C)(C(=O)OCC)C(CC=C)(OCC)C(=O)OCC</smiles><smiles>C#CC(OCC=C)(c1ccccc1)c1ccccc1</smiles><smiles>C=CC[15N]CC=C</smiles>

Scheme 3. Benchmark olefin metathesis transformations used for the evaluation of the pyrene-tagged Ru catalysts. Ts = para-tolylsulfonyl 


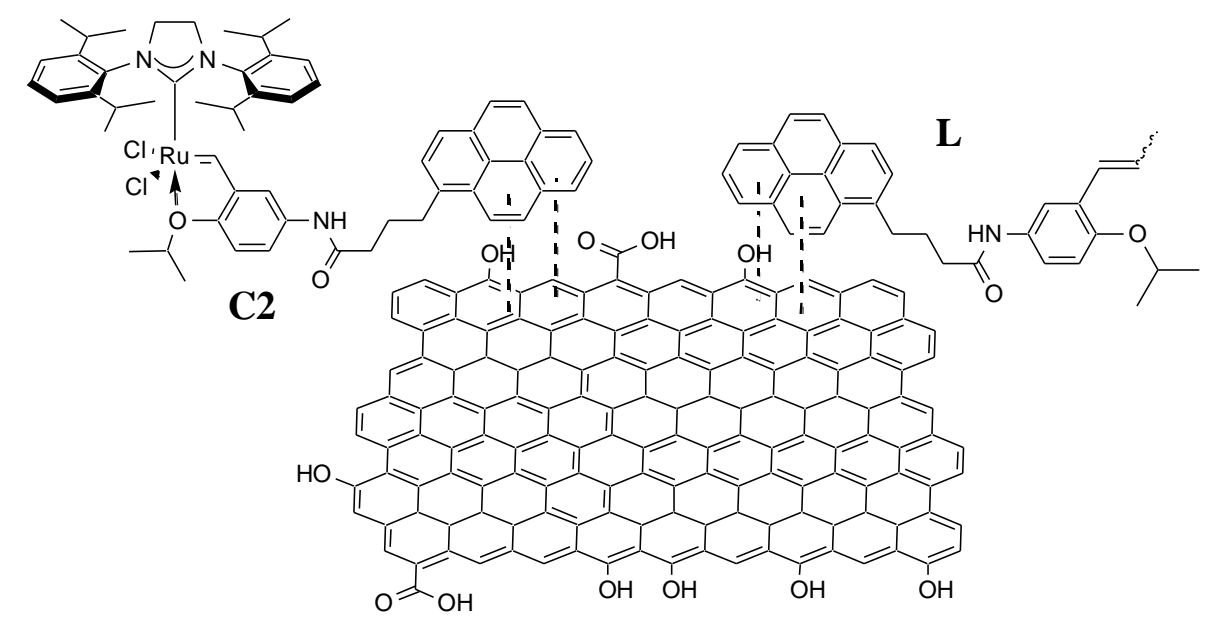

Scheme 4. Schematic representation for the co-immobilization of $\mathbf{C 2}$ with $\mathbf{L}$ on rGO. 
Table 1. Conversion of DEDAM with $\mathbf{C 1}, \mathbf{C 2}$ and $\mathbf{C 3}$ supported on rGO. ${ }^{\text {a) }}$

\begin{tabular}{lllllll}
\hline Entry & $\begin{array}{l}\text { Cat } \\
@ \text { rGO }\end{array}$ & $\begin{array}{l}\text { Cat } \\
/ \mathrm{rGO}^{\mathrm{b})}\end{array}$ & Solvent & $\mathrm{T}\left({ }^{\circ} \mathrm{C}\right)$ & $\mathrm{t}(\mathrm{h})$ & $\begin{array}{l}\text { Conv. } \\
(\%)\end{array}$ \\
\hline 1 & $\mathbf{C 1}$ & $1 / 20$ & DCM & 40 & 1 & 57 \\
2 & $\mathbf{C 1}$ & $1 / 20$ & Toluene & 40 & 1 & 83 \\
3 & $\mathbf{C 1}$ & $1 / 20$ & Toluene & 50 & 1 & 99 \\
4 & $\mathbf{C 1}$ & $1 / 40$ & Toluene & 60 & 1 & 91 \\
5 & $\mathbf{C 2}$ & $1 / 20$ & DCM & 40 & 2 & 71 \\
6 & $\mathbf{C 2}$ & $1 / 40$ & DCM & 40 & 2 & 55 \\
7 & $\mathbf{C 2}$ & $1 / 40$ & DCM & 40 & 2 & $88^{\mathrm{c}}$ \\
8 & $\mathbf{C 2}$ & $1 / 40$ & Toluene & 40 & 1 & $95^{\mathrm{c}}$ \\
9 & $\mathbf{C 2}$ & $1 / 40$ & Toluene & 60 & 0.5 & $\left.99^{\mathrm{c}}\right)$ \\
10 & $\mathbf{C 3}$ & $1 / 40$ & DCM & 40 & 1 & $3^{\mathrm{c})}$ \\
11 & $\mathbf{C 3}$ & $1 / 40$ & Toluene & 60 & 1 & $28^{\mathrm{c})}$ \\
\hline
\end{tabular}

a) reaction conditions: [DEDAM] $=0.1 \mathrm{M}$, conversion determined by GC analysis using pentadecane as internal standard. ${ }^{\text {b) }} \mathrm{cat} / \mathrm{rGO}(\mathrm{w} / \mathrm{w}) .{ }^{\mathrm{c})}[\mathrm{DEDAM}]=0.2 \mathrm{M}$. 
Table 2. Conversion of DEDAM with C2@ $\mathrm{rGO}$ - Recycling studies. ${ }^{\text {a) }}$

\begin{tabular}{lll}
\hline Run & $\mathrm{T}\left({ }^{\circ} \mathrm{C}\right)$ & Conversion $(\%)$ \\
\hline 1 & 60 & 99 \\
2 & 60 & 99 \\
3 & 60 & 95 \\
4 & 75 & $70(85)^{\mathrm{b})}$ \\
5 & 75 & $52(62)^{\mathrm{b})}$ \\
\hline
\end{tabular}

a) reaction conditions : [DEDAM] $=0.2 \mathrm{M}$ in toluene, $0.5 \mathrm{~h}$ reaction time, conversion determined by GC analysis using pentadecane as internal standard, $\left.\mathbf{C} 2 / \mathrm{rGO}=1 / 40(\mathrm{w} / \mathrm{w}) .{ }^{\mathrm{b}}\right) 1 \mathrm{~h}$ reaction time. 
Table 3. Conversion of DEDAM with C2/L@ $\mathrm{rGO}$ - Recycling studies. ${ }^{\text {a) }}$

\begin{tabular}{llllll}
\hline Entry & Run & $\mathrm{T}\left({ }^{\circ} \mathrm{C}\right)$ & $\mathrm{t}(\mathrm{h})$ & Conv. $(\%)^{\mathrm{a})}$ & Table 2 \\
\hline 1 & 1 & 60 & 0.5 & 99 & 99 \\
2 & 2 & 60 & 0.5 & 99 & 99 \\
3 & 3 & 60 & 0.5 & 95 & 95 \\
4 & 4 & 75 & 0.5 & 87 & 70 \\
5 & & 75 & 1 & 95 & 85 \\
6 & 5 & 75 & 0.5 & 75 & 52 \\
7 & & 75 & 1 & 96 & 62 \\
8 & 6 & 75 & 0.5 & 60 & \\
9 & & 75 & 1 & 71 & \\
10 & & 75 & 2 & 78 & \\
11 & 7 & 75 & 0.5 & 19 & \\
12 & & 75 & 16 & 42 & \\
\hline
\end{tabular}

a) reaction conditions: [DEDAM] $=0.2 \mathrm{M}$ in toluene, conversion determined by GC analysis using pentadecane as internal standard, $\mathbf{C} 2 / \mathrm{rGO}=1 / 40(\mathrm{w} / \mathrm{w}), 4$ equiv. ligand $\mathbf{L} /$ cata $\mathbf{C 2}$. 
Table 4. Conversion of DEDAM with C2@ graphene - Recycling studies. ${ }^{\text {a) }}$

\begin{tabular}{lllll}
\hline Entry & Run & Solvent & $\mathrm{T}\left({ }^{\circ} \mathrm{C}\right)$ & Conv. (\%) \\
\hline 1 & 1 & toluene & 60 & 99 \\
2 & 2 & toluene & 60 & 93 \\
3 & 3 & toluene & 60 & 12 \\
4 & DCM & 40 & 99 \\
5 & 1 & DCM & 40 & 98 \\
6 & 2 & DCM & 40 & 87 \\
7 & 3 & DCM & 40 & 47 \\
\hline a) reaction conditions : [DEDAM] $=0.2 \mathrm{M}, 0.5 \mathrm{~h}$ reaction time, conversion determined by NMR analysis using \\
mesitylene as internal standard, C2/graphene = $1 / 40(\mathrm{w} / \mathrm{w})$.
\end{tabular}


Table 5. Conversion of different substrates with $\mathbf{C 2 / L} @$ rGO - Recycling studies. ${ }^{\text {a) }}$

\begin{tabular}{lllll}
\hline Run & Product & $\mathrm{t}(\mathrm{min})$ & $\begin{array}{l}\text { Conversion } \\
(\%)\end{array}$ & Yield (\%) \\
\hline 1 & P1 & 60 & 99 & 99 \\
2 & $\mathbf{P 2}$ & 45 & 99 & 84 \\
3 & $\mathbf{P 3}$ & 45 & 99 & 94 \\
4 & $\mathbf{P 1}$ & 120 & $85^{\mathrm{b}}$ & 84 \\
5 & $\mathbf{P 2}$ & 330 & $15^{\mathrm{b}}$ & nd \\
\hline a) & reaction conditions : [substrates] $=0.2 \mathrm{M}$, conversion determined by $\mathrm{GC}$ analysis using pentadecane as internal \\
standard, $\mathbf{C 2} / \mathrm{rGO}=$ & 1/40 (w/w), 4 equiv. ligand $\mathbf{L} / \mathbf{C 2}, 60^{\circ} \mathrm{C}$ in toluene. ${ }^{\text {b) }}$ reaction conducted at $75{ }^{\circ} \mathrm{C}$.
\end{tabular}

